\title{
Toward Coherent Federal Oversight of Medicine
}

\author{
PATRICIA J. ZETTLER*
}

\begin{abstract}
The conventional wisdom in U.S. health law and policy holds that states regulate medical practice - the activities of physicians and other health care professionals - while the federal government regulates medical products. But relying on states as the principal regulators of medical practice has, at times, driven law and policy in directions that are problematic from a public health perspective, as demonstrated by a deadly 2012 outbreak of fungal meningitis that was linked to a primarily stateregulated practice known as drug compounding. This Article argues that the federalism concerns underlying the conventional wisdom are misplaced. It demonstrates that, contrary to conventional wisdom, the federal government is deeply entangled in regulating medical practice, and such federal regulation is lawful. After examining the goals of federalism within the context of medicine, this Article proposes an alternate paradigm for guiding decisions about when the federal government should be involved in overseeing medicine: Congress and administrative agencies
\end{abstract}

* (C) 2015 Patricia J. Zettler. The author is a an Associate Professor at Georgia State University College of Law. She served as an attorney in the U.S. Food and Drug Administration's Office of Chief Counsel from 2009 to 2013. The author would like to thank Jonathan Abel, Hank Greely, Daniel Ho, Cathy Hwang, Matthew Jordan, Dmitry Karshtedt, Bernard Lo, Paul Lombardo, Eleanor Mayer, Michelle Mello, Seema Shah, Jacob Sherkow, Kayte Spector-Bagdaddy, David Studdert, and the Stanford Law School Fellows for their helpful comments and critiques. Thanks also to Keri Gross, J.D. Candidate 2016, Santa Clara University School of Law, for her terrific research assistance. All mistakes are, of course, the author's own. Please direct all comments to pzettler@gsu.edu. 
should exert federal authority when medical practice contributes to a national public health problem that states cannot address. This framework is applied to one pressing public health problem to which medical practice contributes - antibiotic resistance - to show how the framework could be implemented. Federal oversight of medical practice under this framework would be more principled and transparent than the scheme of federal control that is in place today.

\section{TABLE OF CONTENTS}

I. INTRODUCTION

II. The Conventional Wisdom: Federalism and the Practice

OF MEDICINE

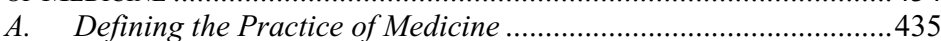

B. The Absence of Federal Regulation …….......................................438

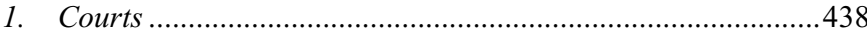

2. Medical Practitioners and Congress ......................................441

C. $\quad$ The Presence of State Regulation ...............................................446

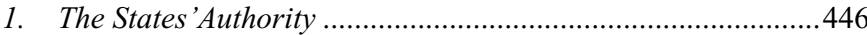

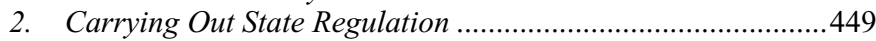

III. Challenging THE CONVENTIONAL WiSDOM ..........................................44

A. Examples of Federal Regulation ....................................................454

1. Direct Regulation..................................................................455

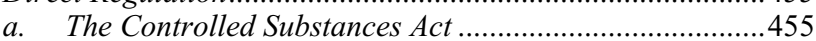

b. Use of Human Growth Hormone ....................................457

c. The Partial-Birth Abortion Ban Act .................................459

2. Indirect Regulation ............................................................460

a. FDA's Pre-Market Authorization of Drugs,

Devices, and Biologics.

b. FDA-Required Risk Evaluation and Mitigation Strategies..........................................................462

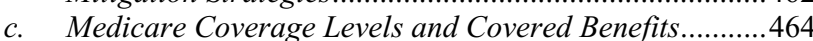

B. $\quad$ Far-Reaching Federal Powers.......................................................467

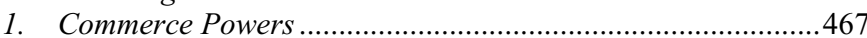

2. Spending Powers ............................................................. 470

3. Taxing Powers ....................................................................... 472

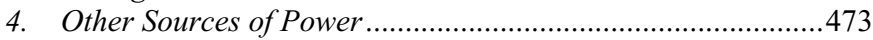

C. What to Make of the Existing Federal Oversight ...........................474

IV. WHEN FEDERAL REGULATION IS WARRANTED .........................................4 477

A. The Case for Federal Regulation .....................................................478

B. A Public Health Framework for Federal Regulation.....................482

1. Advantages of the Framework .............................................483

2. Addressing Critiques.................................................................485

C. Applying the Framework: Antibiotic Resistance …….........................489

1. Antibiotic Resistance Fits the Framework .............................490

a. The National Antibiotic Resistance Problem ...................490

b. States Cannot Adequately Address the Problem ..............492

2. Implementing the Framework for Antibiotic Resistance.

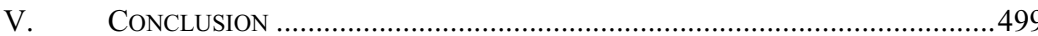




\section{INTRODUCTION}

In the fall of 2012, an outbreak of fungal meningitis sickened 751 and killed 64 people in the United States. ${ }^{1}$ The outbreak was traced to tainted steroid injections made by the New England Compounding Center, a pharmacy in Massachusetts. ${ }^{2}$ The Centers for Disease Control and Prevention (CDC) concluded that the tainted drugs reached approximately 14,000 patients in 23 states, which, combined with the number of fatalities and sickened patients, made this outbreak one of the worst U.S. public health disasters in recent history. ${ }^{3}$

In the Congressional hearings that followed, the U.S. Food and Drug Administration (FDA) was criticized for failing to prevent this outbreak. ${ }^{4}$ Yet the FDA's authority to prevent the outbreak was unclear because the tainted drugs were made through a practice known as "drug compounding,", rather than through traditional drug manufacturing. ${ }^{6}$ That is, the FDA

1. See Multi-State Outbreak of Fungal Meningitis and Other Infections, CENTERS FOR Disease CONTROL AND PREVENTION (Oct. 23, 2013) [hereinafter Multi-State Outbreak], http://www.cdc.gov/hai/outbreaks/meningitis.html [http://perma.cc/4SUD-6YSM].

2. See id.

3. See Pharmacy Compounding: Implications of the 2012 Meningitis Outbreak: Hearing Before the S. Comm. on Health, Education, Labor, and Pensions, 112th Cong. 14 (2012) (statement of Sen. Tom Harkin, Chairman, S. Comm. on Health, Education, Labor, and Pensions) [hereinafter 2012 HELP Compounding Hearing], available at $\mathrm{http} / / /$ www.help.senate.gov/hearings/hearing/?id=5f5def0d-5056-a032-5297-eab57634d209 [http://perma.cc/9KQF-9AQ3]; Multi-State Outbreak, supra note 1. In fact, in 2014, the owners of the New England Compounding Center were arrested and indicted on 131 counts, including charges of racketeering, mail fraud, conspiracy, and second-degree murder. See Jess Bidgood \& Sabrina Tavernise, Pharmacy Executives Face Murder Charges in Meningitis Deaths, N.Y. TIMES, Dec. 18, 2014, at A23.

4. See, e.g., Rob Stein, Lawmakers Clash with FDA over Meningitis Outbreak, NPR.ORG (Nov. 14, 2012, 5:57 PM), http://www.npr.org/blogs/health/2012/11/14/165 156555/congressmen-clash-with-fda-over-meningitis-outbreak [http://perma.cc/N2PK-PYE5].

5. Drug compounding involves a medical practitioner combining, mixing, or altering drug ingredients to create an individualized medication for a patient. See 2012 HELP Compounding Hearing, supra note 3 (testimony of Margaret A. Hamburg, Commissioner, Food \& Drug Admin.); Kevin Outterson, Regulating Compounding Pharmacies after NECC, 367 New ENG. J. MED. 1969, 1971 (2012).

6. See 2012 HELP Compounding Hearing, supra note 3. Before 1992 the FDA generally declined to regulate drug compounding. In 1992, concerned about the risks of large-scale compounding, the FDA announced a policy describing when it considered compounding to be within its purview. Among the activities the FDA identified as triggering regulation was advertising compounding services. In 1997, Congress added section 503A to the Federal Food, Drug, and Cosmetic Act to codify the FDA's 1992 policy. In 2002, the Supreme Court invalidated the advertising provisions of section 503A 
lacked clear authority because the contaminated drugs were made by a pharmacy, an activity that falls within the "practice of medicine", traditionally regulated by state law, rather than by a federally regulated drug manufacturer.

This division of labor between the states and the federal government will be unsurprising to those familiar with U.S. health law and policy. Arising in part from courts' longstanding recognition that the states are authorized to regulate medical practice pursuant to their police powers, ${ }^{8}$ the conventional wisdom among courts, lawmakers, and administrative agencies is that states regulate medical practice, while the federal government regulates medical products. For example, in United States $v$. Evers, the Fifth Circuit explained that, while the FDA "was obviously intended to control the availability of drugs for prescribing by physicians," it "was not intended to regulate the practice of medicine." Similarly, in United States $v$. Regenerative Sciences, LLC, Judge Rosemary M. Collyer of the D.C. District Court noted that the "Defendants state[d] that Congress has left the practice of medicine to the States to regulate, [and] FDA does not disagree with these principles." 10

The discourse following the 2012 fungal meningitis outbreak demonstrated the endurance of these ideas. Despite the public health stakes illustrated by the outbreak, members of Congress continued to express concern about intruding on state regulation of medical practice when designing the Drug Quality and Security Act of 2013, which was enacted in part to remedy the FDA's limited authority over compounding pharmacies. ${ }^{11}$ Senator

in a decision that left the validity of the rest of section 503A in question. See Thompson v. W. States Med. Ctr., 535 U.S. 357, 377 (2002). At the time of the 2012 fungal meningitis outbreak, there was a circuit split regarding the severability of the unconstitutional advertising provisions of section 503A, and consequently, the extent of the FDA's authority over compounding was quite unclear. See Med. Ctr. Pharmacy v. Mukasey, 536 F.3d 383, 387 (5th Cir. 2008); W. States Med. Ctr. v. Shalala, 238 F.3d 1090, 1096-98 (9th Cir. 2001); Outterson, supra note 5, at 1969-71.

7. This Article uses the phrase "practice of medicine" broadly to include the practice of pharmacy, the practice of dentistry, and other health-related practices that states traditionally regulated. Thus, medical practitioners in this Article include physicians, dentists, pharmacists, and other professionals authorized to independently practice medicine.

8. See, e.g., Dent v. West Virginia, 129 U.S. 114, 122-23, 128 (1889).

9. 643 F.2d 1043, 1048 (5th Cir. 1981).

10. 878 F. Supp. 2d 248, 255 (D.D.C. 2012), aff'd, 741 F.3d 1314 (D.C. Cir. 2014); see also Richard Epstein, The FDA's Misguided Regulation of Stem-Cell Procedures: How Administrative Overreach Blocks Medical Innovation, LEGAL POL'Y REP., Sept. 2013, at 2, available at http://www.manhattan-institute.org/pdf/lpr_17.pdf [http://perma.cc/8245EERC] (describing the regulation of medical practice as distinct from the FDA's regulation of drugs and biologics).

11. Title I of the Drug Quality and Security Act addresses drug compounding, while Title II is intended to improve the security of the drug supply chain. See Drug Quality and Security Act of 2013, Pub. L. No. 113-54, 127 Stat. 587 (2013). 
Tom Coburn, speaking in support of the new law, emphasized that it properly left practice-of-medicine issues to the states "so the art and science of medicine would not be impeded by FDA." 12 Additionally, the new law left some significant holes in federal authority, such as making federal licensing for large-scale compounding pharmacies optional rather than mandatory. ${ }^{13}$ It appears that Congress made licensing optional because it could not agree on what constitutes traditional compounding, which would be left to state regulation, versus drug manufacturing, which would be subject to federal requirements. ${ }^{14}$ In other words, Congress could not agree on where to draw the line between the practice of medicine and the manufacturing of a drug product. The gaps in federal authority resulting from this impasse may leave the United States at risk for another public health disaster. ${ }^{15}$

Although concerns about federal interference with the practice of medicine often arise in the FDA context, the FDA's jurisdiction is but one area among many in health law and policy that have been affected by these concerns. Concerns about federal control of medical practice-including legal concerns about the limits of the federal government's constitutional and statutory authority over medicine, as well as policy concerns about the wisdom of federal control-have played a role in shaping healthcare reform, ${ }^{16}$ controlled substances policy, ${ }^{17}$ Medicare, ${ }^{18}$ and the oversight of medical practitioners' business practices ${ }^{19}$ among other things. Likewise, federal agencies other than the FDA, including the Centers for Medicare and Medicaid Services, ${ }^{20}$ the Drug Enforcement Administration, ${ }^{21}$ and the

12. 159 CONG. REC. S8029-06 (daily ed. Nov. 14, 2013) (statement of Sen. Coburn).

13. See Drug Quality and Security Act of 2013, Pub. L. No. 113-54, § 102, 127 Stat. 587, 592-93 (2013); Kevin Outterson, The Drug Quality and Security Act-Mind the Gaps, 370 NEw ENG. J. MED. 97, 98 (2014) [hereinafter Outterson, DQSA].

14. See Outterson, DQSA, supra note 13, at 98 .

15. Cf. id ("[If] another tragedy similar to the one involving the NECC is to be avoided, additional action [beyond the Drug Quality and Security Act] is needed.").

16. See infra notes 76-82, 86-88 and accompanying text.

17. See infra notes 54, 171-73 and accompanying text.

18. See infra notes 78,85 and accompanying text.

19. See infra notes 92-94 and accompanying text.

20. See, e.g., Coll. of Am. Pathologists v. Heckler, 734 F.2d 859, 867 (D.C. Cir. 1984).

21. See, e.g., Jane C. Ballantyne, Regulation of Opioid Prescribing: Over-Regulation Compromises Doctors' Ability to Treat Pain, 334 BRIT. MED. J. 811, 811-12 (2007). 
Federal Trade Commission, ${ }^{22}$ have been criticized on both legal and policy grounds for exerting authority over medical practice.

But these federalism concerns over the practice of medicine are misplaced. State regulation arose at a time when the practice of medicine was largely unregulated and quite provincial-medicine was dominated by unlicensed solo practitioners who treated patients with self-made remedies, local differences in practice standards were to be expected, and courts viewed the federal government's commerce powers as quite limited. ${ }^{23}$ While the traditional view that the federal government should not regulate medical practice may have been reasonable in those circumstances, this view does not account for advances in technology and scientific understanding that have changed medicine into a national field with a recognized impact on the national public health. Moreover, the traditional view fails to acknowledge the ways in which the federal government currently does control medical practice, as well as the porousness of the practice-products distinction. Consequently, determining whether an activity constitutes medical practice is not a useful way to decide whether the states or the federal government should regulate that particular activity.

Instead, when deciding whether to exert federal authority, Congress and federal administrative agencies should consider whether the activity causes or contributes to a national public health problem that states cannot address. This framework proposes a role for the federal government in regulating medical practice that is both broader and narrower than the role that the federal government currently plays. While other scholars have embraced the idea that the federal government should regulate particular aspects of medical practice, ${ }^{24}$ or explicitly argued that the federal government has the constitutional authority to regulate medical practice, ${ }^{25}$ this Article considers the goals of federalism in the context of medicine and proposes

22. See, e.g., Brief of the American Dental Ass'n, American Medical Ass'n, et al., as Amici Curiae in Support of Petitioner, N.C. State Bd. of Dental Exam'rs v. FTC, 135 S. Ct. 1101 (2015) (No. 13-534) [hereinafter Amicus Brief of the American Dental Ass'n et al.].

23. See generally James C. Mohr, Licensed to Practice: The Supreme Court DeFines THE AMERICAN MEDICAL PROFESSION (2013).

24. See, e.g., Yaniv Heled, The Regulation of Genetic Aspects of Donated Reproductive Tissue-The Need for Federal Regulation, 11 Colum. SCI. \& TECH. L. REV. 243, 243 (2010); Jaime S. King, Predicting Probability: Regulating the Future of Preimplantation Genetic Screening, 8 Yale J. Health Pol'y L. \& EThics 283, 331 (2008); William M. Sage \& David A. Hyman, Combating Antimicrobial Resistance: Regulatory Strategies and Institutional Capacity, 84 TUL. L. REV. 781, 823-24 (2010); Michael S. Young \& Rachel K. Alexander, Recognizing the Nature of American Medical Practice: An Argument for Adopting Federal Medical Licensure, 13 DePaul J. Health CARe L. 145, 166-67 (2010).

25. See Lars Noah, Ambivalent Commitments to Federalism in Controlling the Practice of Medicine, 53 U. KAN. L. REV. 149, 161 (2004). 
a general framework for determining when federal regulation of medical practice is warranted. Implementing the proposed framework could open new options for federal legal interventions to address serious public health problems.

Part II of this Article traces the history of the conventional wisdom that the states govern medical practice, and describes how the states have carried out medical practice regulation. Part III argues that, contrary to the conventional wisdom, the federal government is deeply entangled in regulating medical practice. This regulation is both direct, as with the Controlled Substances Act's rules about prescribing drugs of abuse, ${ }^{26}$ and indirect, as with Medicare coverage decisions ${ }^{27}$ and even certain patents. ${ }^{28}$ Additionally, Part III demonstrates that there is nothing unlawful about such examples of federal oversight of medical practice-the Constitution permits the federal government to regulate most, if not all, medical practice. Part III also offers an explanation for why these instances of federal regulation have been accepted despite the maxim that states are the primary regulators of medical practice, and suggests that the current approach to federal oversight is opaque and inconsistent, which drives law and policy in directions that are problematic at times. Given that the federal government currently exerts, or fails to exert, its authority over medicine in ways that are problematic in some circumstances, the question then, is in what circumstances should the federal government intervene?

Part IV answers that question by considering the goals of federalism. Because federal control of medicine has its own potential drawbacks and states may be better positioned to regulate some aspects of medical practice, Part IV argues that the federal government should oversee only those aspects of medical practice that cause or contribute to national public health problems that the states cannot address. Depending on the problem to be addressed, this federal oversight might include direct requirements that expressly restrict the behaviors of practitioners and may preempt state oversight, or indirect forms of regulation, such as conditions on federal funds given to medical practitioners or state governments. Part IV also suggests that abandoning the conventional wisdom would open new avenues for addressing serious public health crises, such as the problem

26. See infra notes $160-70$ and accompanying text.

27. See infra notes 214-31 and accompanying text.

28. See infra notes $277-83$ and accompanying text. 
of drug-resistant bacteria, through federal legal action, and examines how the framework proposed in this Article could be implemented.

Because medical practice has a profound impact on the health and economy of the United States, effectively regulating it presents important and challenging legal and policy questions. This Article helps to address those questions by proposing an implementable framework that incorporates both the goal of protecting the public health and the goal of preserving the benefits of a federalist system of government. While this framework presents potential line-drawing problems because it may be difficult to determine what is a national public health problem that states cannot address, it nevertheless improves on the conventional wisdom by counseling lawmakers and federal administrative agencies to exert federal authority over medical practice in a principled and transparent manner.

\section{THE CONVENTIONAL WISDOM: FEDERALISM AND THE PRACTICE OF MEDICINE}

The states, rather than the federal government, have a long history of regulating the practice of medicine. The earliest American laws controlling the practice of medicine were enacted by the colonies, ${ }^{29}$ and the modern era of medical practice regulation began in 1873, when Texas established county medical boards to license practitioners. ${ }^{30}$ The states continue to actively regulate medical practice. To assess the balance between federal and state power over the practice of medicine, it is useful

29. See Robert C. Derbyshire, Medical Licensure AND Discipline In the United STATES 1-7 (1969).

30. See id. at 7; Timothy Stoltzfus Jost, Oversight of the Quality of Medical Care: Regulation, Management, or the Market?, 37 ARIZ. L. REV. 825, 828 (1995); Henry E. Sigerist, The History of Medical Licensure, 104 J. AM. MED. Ass'N 1057, 1060 (1934). Although physician licensure first appeared in the seventeenth century, those earlier licensure policies were "guild-like" and largely abandoned by 1850 . Jost, supra, at 828 . Texas's licensing law established the first modern medical boards by requiring counties to appoint boards "to be composed of not less than three practicing physicians of known ability, and graduates of some medical college, recognized by the American Medical Association." Under the law, no person was permitted to practice medicine in Texas unless that person had received "the degree of "doctor of medicine" from a "regularly established and well accredited medical college," or "a certificate of qualification from some authorized board of medical examiners." GeORGE W. PASCHAL, A DigeST OF THE LAWS OF TEXAS: CONTAINING THE LAWS IN ForCE AND THE REPEALED LAWS ON WHICH RigHTS REST FROM 1754 TO $18751478 f-1478 g$ (4th ed. 2012). The legislative history does not provide much insight into why the Texas legislature enacted this law. See S. JournaL, 13th Leg., 805-807 (Tex. 1873). It may simply have been a sign of the times. In the late nineteenth and early twentieth century the medical profession was becoming more organized and standardized, and at least certain factions of the profession were lobbying for licensing. See, e.g., Paul Starr, The Social Transformation of American MEDICINE 79-145 (1982); MoHR, supra note 23, at 15. 
to consider the history of state regulation and how states implement medical practice regulation.

\section{A. Defining the Practice of Medicine}

As a preliminary matter, it is helpful to understand what the term "practice of medicine" encompasses. Definitions have changed over time, and varied across stakeholders and jurisdictions. For example, a 1908 article in the Journal of the American Medical Association defined the practice of medicine simply as the "art of healing," 31 and a 1904 article in the California State Journal of Medicine argued that an individual practices medicine when the "relations of the parties [a]re those of physician and patient." ${ }^{32}$ But some state courts at the time did not consider an individual to be practicing medicine unless he administered drugs or performed surgery. ${ }^{33}$

Modern legal definitions of the practice of medicine come from state statutes and courts, and what constitutes the practice of medicine often differs between states. ${ }^{34}$ As an example, an Arizona statute defines the practice of medicine as "the diagnosis, the treatment or the correction of ... any and all human diseases, injuries, ailments, infirmities, deformities, physical or mental, real or imaginary, by any means, methods, devices or instrumentalities ...." ${ }_{35}$ An Oregon statute similarly provides that diagnosing, curing, or treating any mental or physical disease is practicing medicine, but also specifically includes in its definition advertising that one is authorized to practice medicine, referring to oneself as a doctor, prescribing drugs, and performing surgery. ${ }^{36}$ Courts in different states

31. Editorial, What Constitutes the Practice of Medicine?, 50 JAMA 368, 368 (1908)

32. William C. Tait, The Legal Definition of the Practice of Medicine, 2 CAL. ST. J. MED. 119, 119 (1904).

33. See, e.g., Smith v. Lane, 31 N.Y. Sup. Ct. (24 Hun) 632, 634-35 (1881); see also Nelson v. State Bd. of Health, 157 S.W. 501, 505 (Ky. 1900) (holding that an osteopath is not required to be licensed because he does not "prescribe or administer medicine or perform surgery"); State v. Liffring, 55 N.E. 168, 168-69 (Ohio 1899) (concluding that a treatment is not medical practice unless it includes the administration of drugs); State v. Mylod, 40 A. 753, 755-56 (R.I. 1898) (noting that the practice of medicine "requires a knowledge of drugs").

34. See, e.g., Cynthia Marietta \& Amy L. McGuire, Direct-to-Consumer Genetic Testing: Is It the Practice of Medicine?, 37 J.L. MED. \& ETHICs 369, 371 (2009).

35. ARIZ. REV. STAT. ANN. § 32-1401 (2008).

36. OR. REV. STAT. § 677.085 (2013). 
have sometimes reached divergent conclusions about whether the same activities constitute medical practice, perhaps understandably given differences in the underlying statutory language. For instance, a federal court in California concluded that reviewing a claim for an insurance company did not constitute the practice of medicine, ${ }^{37}$ while the Arizona Court of Appeals and the Supreme Court of Missouri concluded that such activities were subject to the state medical boards' jurisdiction. ${ }^{38}$ Also, although the District of Columbia Court of Appeals concluded that a physician's testimony as a non-treating expert witness fell within the practice of medicine, ${ }^{39}$ the Missouri Court of Appeals reached the opposite conclusion. ${ }^{40}$ Contemporary scholars have also diverged on whether particular activities constitute medical practice. For example, whereas some scholars have argued that legal injection is not a medical procedure because of its nontherapeutic goal, ${ }^{41}$ others have argued that death row inmates are akin to terminally ill patients and "deserve to be treated as such." 42

Despite these differences, most state statutes and courts currently define the practice of medicine as involving at least two activities: (1) diagnosing a disease, condition, or injury; and (2) prescribing, administering, or providing a treatment for that disease, condition, or injury. ${ }^{43}$ To perform these activities most effectively and provide the highest quality medical care, practitioners generally assert that they need the flexibility to judge what is best for a particular patient. ${ }^{44}$ For example, practitioners' freedom to prescribe an FDA-approved drug "off-label" - that is, for a condition or patient population, or at a dose, not approved by the $\mathrm{FDA}^{45}$ - can

37. See Jakway v. Unum Provident Corp., No. CV01-6753AHM(RZX), 2002 WL 31996043, at*6-7 (C.D. Cal. May 6, 2002).

38. See State Bd. of Registration for the Healing Arts v. Fallon, 41 S.W.3d 474, 478-49 (Mo. 2001); Murphy v. Bd. of Med. Exam'rs, 949 P.2d 530, 536 (Ariz. Ct. App. 1997).

39. See Joseph v. D.C. Bd. of Med., 587 A.2d 1085, 1091 (D.C. 1991).

40. See Missouri Bd. of Registration for the Healing Arts v. Levine, 808 S.W.2d 440, 443 (Mo. Ct. App. 1991).

41. See, e.g., Robert D. Truog et al., Physicians, Medical Ethics, and Execution by Lethal Injection, 311 JAMA 2375, 2375 (2014).

42. Kenneth Baum, "To Comfort Always": Physician Participation in Executions, 5 N.Y.U. J. LEGIS. \& PUB. POL'Y 47, 61 (2001). 162.

43. See, e.g., Marietta \& McGuire, supra note 34 , at 371 ; Noah, supra note 25 , at

44. See, e.g., Eliot Friedson, Profession of Medicine: A Study of the Sociology of APPLIED KNOWLEDGE 384-92 (2d ed. 1988).

45. See, e.g., Rebecca Dresser \& Joel Frader, Off-Label Prescribing: A Call for Heightened Professional and Government Oversight, 37 J.L. MED. \& ETHICs 476, 476 (2009). When the FDA approves a drug or device, it approves that product as safe and effective for a particular use-namely, to treat a particular disease or condition, in a particular patient population. The uses for which the FDA has approved a product are 
benefit a patient by allowing practitioners to incorporate into their practice emerging evidence that may not be sufficient for FDA approval or may not have been presented to the FDA for approval, which provides the patient with additional treatment options. ${ }^{46}$ Arguments in the United States against government - rather than practitioner - control of medical practice have long included assertions that government limits on practitioner discretion will decrease the quality of medical care. ${ }^{47}$ Consistent with the idea that good medical practice is individualized, ethical guidelines counsel practitioners to promote an individual patient's best interests and respect each patient's autonomy. ${ }^{48}$ This focus on the health and best interests of the individual distinguishes medicine from public health, which is concerned with the well-being of an entire population. ${ }^{49}$ As Jeffrey M. Drazen, a physician and editor-in-chief of the New England Journal of Medicine, wrote, the practice of medicine is carried out "on an individual basis, with the best interests of the patient foremost in the practitioner's mind." 50

listed on its FDA-approved label, and thus, using a product for an indication that is not FDA-approved, is known as an "off-label" use. See id.

46. See, e.g., Randall S. Stafford, Regulating Off-Label Drug Use-Rethinking the Role of the FDA, 358 N. ENG. J. MED. 1427, 1427 (2008).

47. $C f$. Jonathan Oberlander, The Political Life of Medicare 22 (2003) (noting that the American Medical Association lobbied against government health insurance in 1949 by arguing that it would "inevitably erode the quality of medical care by giving the government [rather than physicians] control over medical services").

48. See, e.g., Bernard Lo, Resolving Ethical Dilemmas: A Guide for Clinicians 12-14 (5th ed. 2013); $c f$. Canterbury v. Spence, 464 F.2d 772, 780 (D.C. Cir. 1972) (finding that physicians have a duty to obtain informed consent from patients because "every human being of adult years and sound mind has a right to determine what shall be done with his own body"); Samia A. Hurst \& Marion Danis, A Framework for Rationing by Clinical Judgment, 17 KeNNEDY INST. ETHICS J. 247, 248-51 (2007) (discussing physicians' obligations to both ration healthcare resources and advocate for patients' best interests).

49. See, e.g., Lawrence O. Gostin, Public Health Law: Power, Duty, Restraint 4 (2d ed. 2008); see also COMM. FOR the StUdy OF the Future OF Public Health, Inst. of Med., The Future of Public Health 3 (1988) (noting, "public health does things that benefit everybody"); Onyebuchi A. Arah, On The Relationship between Individual and Population Health, 12 Med. HeAlth CARE \& PHIL. 235, 235 (2009) (contending that "population health calls up images of non-individual health").

50. Jeffrey M. Drazen, Government in Medicine, 356 N. ENG. J. MED. 2195, 2195 (2007). 


\section{B. The Absence of Federal Regulation}

Given this focus on practitioner discretion and individualized care, it is perhaps to be expected that courts, medical practitioners, and Congress have not viewed the federal government — and the one-size-fits-all approach that may come with it - as a natural fit for regulating medical practice.

\section{Courts}

Courts have often concluded that the federal government does not regulate medical practice. Throughout the early twentieth century, courts likely would have struck down federal efforts to directly regulate medical practice on constitutional grounds. During the Lochner era, the Supreme Court viewed the federal government's commerce powers as quite limited, ${ }^{51}$ and the doctrine of dual federalism - "the concept that the state and national governments enjoy exclusive and non-overlapping spheres of authority"-held sway. ${ }^{52}$ Moreover, at that time medical practice was decidedly more local in nature than modern medical practice. Many solo practitioners provided care in homes, rather than in offices or hospitals, and prescribed remedies that they made themselves, rather than commercial drugs. 53

In fact, in a 1925 decision, Linder v. United States, the Supreme Court stated that "[o]bviously, direct control of medical practice in the states is beyond the power of the federal government." 54 Since Linder, several lower courts have cited this language to support its stated proposition. ${ }^{55}$

51. See Noah, supra note 25, at 161; see also Molly S. McUsic, The Ghost of Lochner: Modern Takings Doctrine and Its Impact on Economic Legislation, 76 B.U. L. REV. 605, 606-09 (1996) (describing the Lochner era).

52. Robert A. Schapiro, Toward A Theory of Interactive Federalism, 91 IowA L. REV. 243, 246 (2005); see also United States v. E. C. Knight Co., 156 U.S. 1,11 (1895) ("It cannot be denied that the power of a state to protect the lives, health, and property of its citizens ... . [is] essentially exclusive."). The idea that the federal government lacked the constitutional power to regulate medical practice persisted well past the early twentieth century, with at least one medical scholar claiming in 1969 that "the federal government cannot assume this function [of regulating medical practice] without an amendment to the Constitution." DERBYSHIRE, supra 29, at 18.

53. See, e.g., Phillip J. Hilts, Protecting America's Health 19-24 (2003) (describing the transition from doctor-made medications to commercial medicines); STARR, supra note 30, at 60-79 (1982) (describing the end of the solo practitioner era); Nicole Huberfeld, Federalizing Medicaid, 14 U. PA. J. ConST. L. 431, 476 (2011) ("The practice of medicine is increasingly nationalized ....").

54. Linder v. United States, 268 U.S. 5, 18 (1925).

55. See United States v. Singh, 390 F.3d 168, 189-90 (2d Cir. 2004); Oregon v. Ashcroft, 368 F.3d 1118, 1124 (9th Cir. 2004) aff'd sub nom. Gonzales v. Oregon, 546 U.S. 243 (2006); In re Grand Jury Proceedings, 801 F.2d 1164, 1169 (9th Cir. 1986); United States v. Rosenberg, 515 F.2d 190, 198 (9th Cir. 1975); Metrolina Family Practice 
For example, in United States v. Evers, Judge Robert E. Varner of the District Court for the Middle District of Alabama quoted this language to support his decision that a physician promoting and administering an FDA-approved drug for an unapproved use was practicing medicine, not misbranding drugs under federal law. ${ }^{56}$ Similarly, in Oregon v. Ashcroft, the Ninth Circuit quoted this language in holding unlawful a federal directive declaring physician-assisted suicide, which was permitted under Oregon law, to be in violation of the federal Controlled Substances Act. ${ }^{57}$ Yet, in most of the cases in which courts citing Linder considered the validity of a federal statute or action that arguably restricted medical practice, the courts upheld those federal statutes and actions. ${ }^{58}$ In the cases in which a federal action was not upheld-such as Evers and Oregon v. Ashcroft - those holdings relied primarily on the scope of the statute at issue, rather than the scope of the federal government's constitutional authority. ${ }^{59}$

Grp., P.A. v. Sullivan, 767 F. Supp. 1314, 1320-21 (W.D.N.C. 1989) aff'd, 929 F.2d 693 (4th Cir. 1991); United States v. Evers, 453 F. Supp. 1141, 1150 (M.D. Ala. 1978) aff'd, 643 F.2d 1043 (5th Cir. 1981); FTC v. Simeon Mgmt. Corp., 391 F. Supp. 697, 705 (N.D. Cal. 1975) aff'd, 532 F.2d 708 (9th Cir. 1976); Henderson v. Wright, No. 954718D, 1996 WL 33401225, at *2 (Mass. Super. Nov. 27, 1996); cf. United States v. Rosen, 582 F.2d 1032, 1035 (5th Cir. 1978) (citing Linder in determining whether prescribing controlled substances was properly considered the practice of medicine); United States v. Larson, 507 F.2d 385, 388 (9th Cir. 1974) (citing Linder for the proposition that what constitutes medical practice must be determined based upon attending circumstances and a consideration of the evidence); O'Reilly v. Bd. of Med. Examiners, 426 P.2d 167, 171 (Cal. 1967) (citing Linder to uphold a federal exchange program for foreign physicians, "even though the power to regulate the practice of medicine is ordinarily committed to the states"); N.J. Guild of Hearing Aid Dispensers v. Long, 384 A.2d 795, 808 (N.J. 1978) (citing Linder to support the proposition that "[p]rofessional licensing and regulation of professional misconduct are activities which have long been committed to the states ...."). The only Supreme Court opinion that relied on Linder to support the proposition that the federal government cannot regulate medical practice is the dissent in Lambert v. Yellowley, cited infra note 64 , at 214 . $1981)$

56. See 453 F. Supp. 1141, 1150 (M.D. Ala. 1978) aff'd, 643 F.2d 1043 (5th Cir.

57. See 368 F.3d 1118, 1124 (9th Cir. 2004), aff'd sub nom., Gonzales v. Oregon, 546 U.S. 243 (2006).

58. See, e.g., Singh, 390 F.3d at 190; Metrolina Family Practice Grp., P.A., 767 F. Supp. at 1320-21; In re Grand Jury Proceedings, 801 F.2d at 1169-70; Rosenberg, 515 F.2d at 198 .

59. See Evers, 453 F. Supp. at 1150; Gonzales, 368 F.3d. at 1124-25; see also Epstein, supra note 10, at 5 (arguing that FDA cannot regulate certain stem cell procedures because of the limits of its enabling statutes). But see Simeon Mgmt. Corp., 391 F. Supp. at 705 (relying on Linder to hold that the Federal Trade Commission (FTC) is not 
Despite Linder's strong language, its holding is limited and its analysis does not fully support the proposition that the federal government cannot regulate medical practice. ${ }^{60}$ In Linder, the Supreme Court overturned Dr. Charles O. Linder's federal conviction, under the Harrison Anti-Narcotic Act, for prescribing narcotics to relieve a patient's addiction symptoms. ${ }^{61}$ In reversing Dr. Linder's conviction, the Court focused on the limits of what the Harrison Anti-Narcotic Act, a tax law, authorized, rather than on constitutional limits on federal authority. The Court's primary concerns were that applying the statute to the particular set of facts in Linder was "plainly inappropriate and unnecessary to reasonable enforcement of [the] revenue measure," $" 62$ and that Congress did not intend to regulate medical practice through the statute. ${ }^{63}$ Although the Court reversed Dr. Linder's conviction, it did not strike down the law itself. ${ }^{64}$

Additionally, only a year after Linder was decided, the Court concluded that regulating medical practice was not outside the scope of the federal government's constitutional authority in Lambert v. Yellowley. ${ }^{65}$ In Lambert, a physician sought to enjoin enforcement of a provision in the National Prohibition Act of 1919 that limited the amount of liquor that physicians could prescribe, on the grounds that "in certain cases . . . the use of spirituous liquor . . . in an amount exceeding [the limit] [wa]s necessary for the proper treatment of patients," and the "control [of] medical practice in the states is beyond the power of the federal government." The Court rejected these arguments, concluding that "there is no right to practice medicine which is not subordinate to ... the power of Congress

authorized to require physicians to advertise that a drug is not FDA-approved, without discussing the FTC's statutory authority).

60. See Noah, supra note 25 , at 161 ; but see Paul D. Clement \& Laurence H. Tribe, Laboratory Testing Services, as the Practice of Medicine, Cannot Be Regulated as Medical Devices 11 (2015) [hereinafter "Clement \& TRIBE"], available at http://www.acla.com/wp-content/uploads/2015/01/Tribe-Clement-White-Paper-1-6-15.pdf [http://perma.cc/S5MP-R59J].

61. Linder v. United States, 268 U.S. 5, 22 (1925). The Harrison Anti-Narcotic Act imposed a tax on practitioners who distributed narcotics. Id. at 5, 11. Lower courts had interpreted the law as prohibiting physicians from prescribing narcotics solely to relieve patients' addiction symptoms. See id. at 10-12; Harrison Anti-Narcotic Act of 1914, ch. 1,38 Stat. 785

62. Linder, 268 U.S. at 18.

63. See id. at 22-23.

64. Id. at 18; see also Noah, supra note 25, at 161 (noting that "[i]n 1925, the Court upheld the federal government's first controlled substances legislation").

65. 272 U.S. 581, 596-97 (1926); see also Noah, supra note 25, at 161 (describing the Court's opinion in Lambert). But see Lambert, 272 U.S. at 598 (Sutherland, J., dissenting) ("Congress . . . cannot directly restrict the professional judgment of the physician or interfere with its free exercise in the treatment of disease. Whatever power exists in that respect belongs to the states exclusively.").

66. Lambert, 272 U.S. at $588,596$. 
to make laws necessary and proper for carrying into execution the Eighteenth Amendment." 67 The Twenty-first Amendment repealed the Eighteenth Amendment of the Constitution, which prohibited the production, sale, and transport of alcohol. But the Court's logic in Lambert would apply equally to Congress's authority to enact laws necessary and proper for carrying out its other powers.

Lastly, and perhaps most importantly, Linder was decided at a time when courts still endorsed the Lochner-era view of regulation and the doctrine of dual federalism, both of which have long since been repudiated by courts. ${ }^{68}$ Accordingly, even if Linder at one time stood for the proposition that medical practice is beyond the reach of the federal government's constitutional powers, it should no longer be viewed as supporting that proposition. As Lars Noah has argued, "nothing [in the Constitution] requires that the practice of medicine remain sacrosanct as a potential subject of federal regulatory involvement." ${ }^{, 69}$

\section{Medical Practitioners and Congress}

In the absence of a constitutional bar on federal regulation of medical practice, political forces have discouraged federal oversight. Since the turn of the twentieth century, medical practitioners have enjoyed "an especially persuasive claim to [cultural] authority." ${ }^{\prime 70}$ Although the power and solidarity of medical practitioners may be waning, organized medicine continues to possess substantial political influence. ${ }^{71}$ For example, one lobbying study estimated that Congressional legislative assistants meet with physicians 29,000 times per year, and found that legislative assistants ranked $90 \%$ of the physicians with whom they met as either "effective" or "somewhat effective" at communicating their message. ${ }^{72}$ Additionally,

67. Id. at 596 (internal citations omitted).

68. See, e.g., New York v. United States, 505 U.S. 144, 159 (1992) (rejecting dual federalism); Daniel A. Farber, Who Killed Lochner?, 90 GEO. L.J. 985, 1002-03 (2002) (reviewing G. Edward White, The Constitution and the New Deal (2000)) (describing the Court's repudiation of Lochner).

69. Noah, supra note 25, at 192.

70. STARR, supra note 30 , at 4.

71. See Michael J. Malinowski, Doctors, Patients, and Pills-A System Popping Under Too Much Physician Discretion? A Law-Policy Prescription To Make Drug Approval More Meaningful in the Delivery of Health Care, 33 CARDOzo L. REV. 1085, 1092, 1097-98 (2012).

72. See Steven H. Landers \& Ashwini R. Sehgal, How Do Physicians Lobby Their Members of Congress?, 160 ARCHIVES OF INTERNAL MED. 3248, 3248 (2000). 
OpenSecrets.org identifies the American Medical Association (AMA) the largest U.S. association of medical professionals - as one of the 140 biggest overall donors to federal elections since the 1990 election cycle. ${ }^{73}$ Organized medicine has used this clout to lobby against federal legislation that would govern medical practice ${ }^{74}$ and to influence legal proceedings that implicate medical practice regulation. ${ }^{75}$

Historically, medical practitioners' efforts to prevent federal legislation affecting medical practice were quite successful. ${ }^{76}$ The AMA's opposition to federal-government-mandated or -funded health insurance, which began as early as 1920, may offer the longest-running example of organized medicine's successes. ${ }^{77}$ This opposition was partly based on concerns about federal oversight of medical practice ${ }^{78}$ and, with the exception of Medicare, was generally effective during the twentieth century. ${ }^{79}$ For example, the AMA's opposition helped persuade President Franklin D. Roosevelt's administration that health insurance should not be included as part of the Social Security Act of 1935 . A 1939 proposal to provide federal grants to develop state health insurance plans failed to progress out of subcommittee after the AMA produced twenty-two arguments against it, and several other health care reform bills proposed during President Harry S. Truman's administration suffered similar fates. ${ }^{80}$ Consistent with this history, the AMA opposed President Bill Clinton's health care reform proposal in the 1990 s, spending three million dollars in its efforts defeat the Clinton

73. See Center for Responsive Politics, American Medical Assn, OPENSECRETS.ORG, http://www.opensecrets.org/orgs/summary.php?id=D000000068 [http://perma.cc/8SWJ53GH] (last visited Jan. 13, 2015).

74. See, e.g., STARR, supra note 30, at 260. Medical practitioners also have opposed specific instances of state legislation, such as a Florida law restricting physicians' ability to talk about gun ownership with patients and a California bill that would require physicians to limit narcotic prescriptions to no more than a thirty-day supply. See Wollschlaeger v. Farmer, 880 F. Supp. 2d 1251, 1257 (S.D. Fla. 2012); William Heisel, Everybody Hurts: Bill Tackling Prescription Drug Abuse Felled by Cost Concerns, REPORTING ON HEALTH (June 6, 2014), http://www.reportingonhealth.org/2014/06/05/ everybody-hurts-bill-tackling-prescription-drug-abuse-felled-cost-concerns [http://perma.cc/ 62LX-GDJM].

75. See, e.g., Litig. Ctr., About Us, American Medical Association, http://www. ama-assn.org/ama/pub/physician-resources/legal-topics/litigation-center/about-us.page [http:// perma.cc/UMW7-J9TU] (last visited Feb. 7, 2015).

76. See STARR, supra note 30, at 260-61.

77. See id. at 247-48; OBERLANDER, supra note 47, at 19, 21-22.

78. See, e.g., OBERLANDER, supra note 47, at 22; SHANNA ROSE, FinANCING MEDICAID: Federalism AND the Growth of AmericA's Health CARe SAFETy Net 28-29 (2013).

79. See, e.g., Rose, supra note 78, at 27 . For a discussion of the role that the AMA's opposition to Medicare played in the enactment of Medicaid, see $i d$. at 38-46.

80. See, e.g., STARR, supra note 30 , at 269. 
proposal. ${ }^{81}$ Like the other twentieth century predecessors to President Barack Obama's successful health care reform effort, the Clinton Administration's health care reform proposal failed. ${ }^{82}$

In some instances, organized medicine has been able to persuade Congress to include in the legislation affecting medical practice, provisions that disavow any intent to regulate medical practice. ${ }^{83}$ The Social Security Amendments of 1954, for example, provided that "[n]othing in this subchapter shall be construed as authorizing the Commissioner of Social Security or any other officer or employee of the United States to interfere in any way with the practice of medicine. ${ }^{" 84}$ The Medicare statute, ${ }^{85}$ the Fertility Success Rate and Certification Act of $1992,{ }^{86}$ the Food and Drug Administration Modernization Act of $1997,{ }^{87}$ the Drug Addiction Treatment Act of $2000,{ }^{88}$ and the Food and Drug Administration Amendments Act of $2007^{89}$ each included a provision with similar language. Even when a

81. See, e.g., Sam Stein, American Medical Association Trying To Torpedo Health Care Reform Again, HufFINGTON Post (July 11, 2009, 5:12 AM), http://www.huffington post.com/2009/06/11/american-medical-associat_n_214132.html [http://perma.cc/APC6QKT3].

82. See, e.g., Robert J. Blendon et al., What Happened to Americans' Support for the Clinton Health Plan, 14 Health AfF. 7, 8 (1995).

83. See Noah, supra note 25, at 165-66.

84. Social Security Amendments of 1954 , Pub. L. No. 83-761, § 106, 68 Stat. 1052, 1080 (1954) (codified at 42 U.S.C. § 416).

85. Health Insurance for the Aged Act, Pub. L. No. 89-97, § 102(a), 79 Stat. 290, 291 (1965) (codified at 42 U.S.C. § 1395) ("Nothing in [the Medicare statute] shall be construed to authorize any Federal officer or employee to exercise any supervision or control over the practice of medicine.").

86. Pub. L. No. 102-493, § 3(i)(1), 106 Stat. 3146, 3149 (codified at 42 U.S.C. § 263a-2(i)(1)) ("In developing the [federal embryo laboratory] certification program, the [Department of Health and Human Services] may not establish any regulation, standard, or requirement which has the effect of exercising supervision or control over the practice of medicine in assisted reproductive technology programs.").

87. Pub. L. No. 105-115, § 214, 111 Stat. 2296, 2348 (codified at 21 U.S.C. § 396) ("Nothing in [the Federal Food, Drug, and Cosmetic Act] shall be construed to limit or interfere with the authority of a health care practitioner to prescribe or administer any legally marketed device to a patient for any condition or disease within a legitimate health care practitioner-patient relationship.").

88. Pub. L. No. 106-310, § 3502, 114 Stat. 1222, 1226 (codified at 21 U.S.C. $\S$ $823(\mathrm{~g})(2)(\mathrm{H})(\mathrm{i}))$ ("Nothing in such regulations or practice guidelines may authorize any Federal official or employee to exercise supervision or control over the practice of medicine or the manner in which medical services are provided.").

89. Food and Drug Administration Amendments Act of 2007, Pub. L. No. 110-85, $\S 1111(\mathrm{~d}), 121$ Stat. 823, 976 (codified at 42 U.S.C. $\$ 247 \mathrm{~d}-5 \mathrm{a}(\mathrm{d})$ ) ("Nothing in this section 
statute that affects medical practice does not include such provisions, concerns about federal regulation of medical practice may still drive decisions about the law - as demonstrated by the history of the Drug Quality and Security Act. ${ }^{90}$

In addition to resisting legislation that would affect medical practice, the AMA and other medical organizations involve themselves in legal proceedings that implicate medical practice. ${ }^{91}$ For example, ten medical associations, including the AMA and the American Dental Association, filed a joint amicus brief with the Supreme Court in a case about the Federal Trade Commission (FTC) ordering the North Carolina Board of Dental Examiners to stop sending cease-and-desist letters to teeth-whitening providers who were not licensed dentists. ${ }^{92}$ The FTC ordered the Board to stop sending the cease-and-desist letters on the ground that the Board was engaging in unfair competition in violation of federal antitrust law. ${ }^{93}$ In their amicus brief, the medical organizations argued that federal antitrust law did not apply to the Board, and that affirming the FTC's position "would have perverse consequences for patients and the public," and that "Federal overturning of state policy choices ... is particularly inappropriate where, as here, regulation of the health professions is at issue." 94 Generally, federal antitrust law confers immunity to state actors, as medical organizations have argued. ${ }^{95}$ However, because a majority of the Board's members were market participants - licensed dentists and a hygienistelected by other market participants and because the Board's actions were not actively supervised by the state, the Court concluded that the Board's cease-and-desist letters were not covered by state-action immunity. ${ }^{96}$ While the medical organizations' amicus brief was ultimately unsuccessful in achieving their aims in this case, it is one example of medical organizations' opposing federal regulation of medical practice in the litigation setting.

[of the Public Health Service Act] shall be construed to restrict, in any manner, the prescribing of antibiotics by physicians, or to limit the practice of medicine[.]").

90. See supra notes 11-15 and accompanying text.

91. See, e.g., Litig. Ctr., supra note 75; Legal Advocacy and Litigation, AM. DENTAL Ass'N, http://www.ada.org/en/advocacy/legal-advocacy-and-litigation [http://perma. cc/W5VG-6BSF] (last visited Feb. 18, 2015).

92. See N.C. State Bd. of Dental Exam'rs v. FTC, 135 S. Ct. 1101 (2015); Amicus Brief of the American Dental Ass'n et al., supra note 22.

93. See N.C. State Bd. of Dental Exam'rs, 135 S. Ct. at 1108-09.

94. Amicus Brief of the American Dental Ass'n et al., supra note 22, at 2, 13.

95. See N.C. State Bd. of Dental Exam'rs, 135 S. Ct. at 1110 (citing Parker v. Brown, 317 U.S. 341 (1943)).

96. See id. at 1112-14. Justice Alito, joined by Justices Scalia and Thomas, dissented from this opinion and would have found that federal antitrust law did not apply to the Board's actions. Id. at 1118 (Alito, J., dissenting). 
Although there are instances in which organized medicine has supported federal regulation of medical practice, that support was often conditioned on certain protections for practitioners' interests. In 1997, the AMA supported a federal bill that would have prohibited "intact dilation and evacuation" of a fetus - often referred to as a "partial-birth abortion"but only after lawmakers agreed to make clear that physicians could not be prosecuted for resorting to the procedure to save a mother's life after beginning to deliver a baby. ${ }^{97}$ Moreover, the AMA later came to consider this conditional support for the 1997 bill a mistake and it did not support the federal Partial-Birth Abortion Ban Act that was eventually passed in 2003 and upheld by the Supreme Court in Gonzales v. Carhart. 98

Additionally, in a departure from its resistance to healthcare reform in the twentieth century, the AMA and other organizations supported the passage of the Obama administration's health care reform proposal-the Patient Protection and Affordable Care Act of 2010 (PPACA). ${ }^{99}$ Although the PPACA is, perhaps, best known for its provision that subjects individuals who do not purchase health insurance to a financial penaltythe "individual mandate" - one of its goals is to influence medical practice by incentivizing practitioners and hospitals to improve the quality of medical care. ${ }^{100}$ The AMA did support the PPACA, however, it opposed earlier versions of the law that would have created a government-sponsored insurance plan. ${ }^{101}$ The AMA's support for the PPACA may have been

97. See Will an AMA Endorsement Sway Any Votes? A Vote on Late-Term Abortion Ban Is Set for This Afternoon, CNN (May 20, 1997), http://www.cnn.com/ ALLPOLITICS/ 1997/05/20/abortion.ama/ [http://perma.cc/6PSH-ZTNH]; Letter from P. John Seward, Exec. Vice President, Am. Med. Ass'n, to Rick Santorum, U.S. Senator (May 19, 1997), available at http://www.gargaro.com/ama.html [http://perma.cc/SWN5-2ZE6].

98. See Amy Sullivan, A Time to Choose: How Democrats Started Losing the Abortion Debate, WASHINGTON MONTHLY (Dec. 2003), http://www.washingtonmonthly.com/ features/2003/0312.sullivan.html [http://perma.cc/X83Q-PJUC]; Gonzales v. Carhart, 550 U.S. 124, 132-33 (2007).

99. See Patient Protection and Affordable Care Act, Pub. L. No. 111-148, 124 Stat. 119 (2010); Lawrence D. Brown, The Elements of Surprise: How Health Reform Happened, 36 J. Health POL. PoL'y \& L. 419, 424-25 (2011).

100. See Patient Protection and Affordable Care Act $\$ 1501(\mathrm{~b})$; Robert Kocher et al., The Affordable Care Act and the Future of Clinical Medicine: The Opportunities and Challenges, 153 AnNALs of INTERNAL MED. 536, 536-37 (2010).

101. See Robert Pear, Doctors' Group Opposes Public Insurance, N.Y. TIMES, June 10, 2009, http://www.nytimes.com/2009/06/11/us/politics/11health.html?_r=2\&hp\& [http://perma.cc/37HJ-58QM]. It is worth noting that the AMA is not the only medical organization, and at least one group, Physicians for a National Health Program, supports 
motivated by the belief that reform was imminent regardless of practitioners' support, and accordingly, it was best to influence the reform rather than oppose it outright. ${ }^{102}$ In sum, the overall trend in organized medicine has been to oppose federal regulation of medical practice, unless the federal programs protected practitioners' interests or their freedom to care for patients as they see fit.

\section{The Presence of State Regulation}

The states possess broad authority to regulate the practice of medicine pursuant to their police powers. ${ }^{103}$ Against the backdrop of skepticism about federal regulation of medical practice, states have exercised this authority to oversee medical practice in a variety of ways.

\section{The States' Authority}

The states have long regulated the practice of medicine pursuant to their general police power to protect the health, safety, and welfare of state citizens. ${ }^{104}$ States began to use their police powers to establish modern licensing requirements for medical practitioners in the late nineteenth century. ${ }^{105}$ And since at least 1889 , when the Supreme Court decided Dent v. West Virginia, the Court has recognized states' authority in this area. ${ }^{106}$

a single-payer health insurance system. Id. The AMA is, however, the largest medical professional association and wields more power than other groups. See id.

102. See Brown, supra note 99, at 424-25.

103. See, e.g., Watson v. Maryland, 218 U.S. 173, 176 (1910); Edward P. Richards, The Police Power and the Regulation of Medical Practice: A Historical Review and Guide for Medical Licensing Board Regulation of Physicians in ERISA-Qualified Managed Care Organizations, 8 ANNALs HeAlTH L. 201, 218 (1999).

104. U.S. Const. amend. X. See also Slaughter-House Cases, 83 U.S. 36, 62 (1872) (describing the police power as extending "to the protection of the lives, limbs, health, comfort, and quiet of all persons . . . within the State"); Noah, supra note 25, at 159 ("The Supreme Court long ago recognized that the police powers of the states justified their regulation of the practice of medicine.").

105. Before then, virtually anyone, regardless of qualifications or credentials, was free to call himself "doctor" and treat, or, perhaps more accurately, attempt to treat, patients. Although the state - and federal-governments' failure to play any gatekeeping role for medical practitioners may seem irresponsible, the lack of regulation may have made sense at the time. Scientific knowledge was limited, and there were several different schools of medical practice, none of which were particularly effective. Accordingly, there were few principled bases on which to decide who should, and should not, practice medicine. See, e.g., MoHR, supra note 23, at 9-21.

106. See 129 U.S. 114, 128 (1889); Jost, supra note 30, at 827. 
Dent involved a West Virginia licensing statute that was enacted in 1881. ${ }^{107}$ The law was passed following determined lobbying efforts in its support by the Medical Society of West Virginia, which was founded with the goal of transforming medical practice from an unregulated profession that included "dangerous pretenders and quacks" into a "learned, sciencebased, and legally-licensed profession." 108 The law required every medical practitioner in the state to obtain a certificate from a state board affirming that "he is a graduate of a reputable medical college ... he has practiced medicine in the state continuously for the period of 10 years prior to the 8th day of March, 1881", or he has been found, upon examination by the board, to be qualified to practice medicine. ${ }^{109}$ Practicing medicine without such a certificate was a misdemeanor offense. ${ }^{110}$

At the time the law was passed, the plaintiff, Frank Dent, had practiced medicine in West Virginia for seven years as an independent practitioner, and for five more years as an apprentice to his father. ${ }^{111}$ The state board refused to count his five-year apprenticeship when calculating his years of practice, and accordingly, refused to issue him a certificate because he had not practiced medicine for the requisite ten years. ${ }^{112}$ Dent subsequently received a medical degree, but the board determined that the school granting it was not a reputable one, and again refused to grant him a certificate. ${ }^{113}$ Despite the board's refusals, Dent continued to practice and was convicted of practicing medicine without a certificate. ${ }^{114}$

After his conviction, Dent challenged the licensing statute on the ground that it violated his Fourteenth Amendment right to due process because, having established a medical practice in West Virginia, he had a property

107. See MoHR, supra note 23, at 63-79.

108. See id. at 27-28, 63-79.

109. Dent, 129 U.S. at 114

110. See id. Those convicted of practicing without a certificate would be subject to "fines between $\$ 50$ and $\$ 500$, or imprisonment between thirty days and one year, or some combination of both." MoHR, supra note 23, at 69. These penalties could be applied to "each and every" offense, meaning that a practitioner could be subject to up to $\$ 500$ in fines and one year in prison for each visit with each patient that he saw. Id.

111. See MOHR, supra note 23, at 99.

112. Id.

113. See id. at 100-03.

114. See Dent, 129 U.S. at $117-18$. It is worth noting that Frank Dent came from a family that had practiced medicine in West Virginia for four generations, and more importantly, had clashed with the politically powerful founder of the Medical Society of West Virginia. For a comprehensive discussion of the facts and politics that led to Dent's conviction and subsequent litigation, see MoHR, supra note 23. 
right in his practice. ${ }^{115}$ The Court rejected Dent's argument and upheld West Virginia's licensing requirement as within " $[\mathrm{t}]$ he power of the state to provide for the general welfare of its people." 116 The Court explained that, while

[i]t is undoubtedly the right of every citizen of the United States to follow any lawful calling, business, or profession he may choose, ... there is no arbitrary deprivation of such right where its exercise is not permitted because of a failure to comply with conditions imposed by the state for the protection of society. ${ }^{117}$

Since Dent, courts have upheld a broad range of state medical practice laws against constitutional challenges, making clear that states are generally authorized to legislate in the medical practice area, ${ }^{118}$ and that courts are reluctant to recognize a First or Fourteenth Amendment right to be free from such regulation. For example in 1921, the Supreme Court upheld a Minnesota law that prohibited medical practitioners from dispensing narcotics directly to addicts despite arguments that the law violated the Fourteenth Amendment and was preempted by federal law. ${ }^{119}$ In 1997, the Court rejected Fourteenth Amendment challenges to New York and Washington's laws prohibiting physician-assisted suicide. ${ }^{120}$ In 2012, the Eighth Circuit was not persuaded by abortion providers' arguments that a South Dakota law requiring that physicians inform patients seeking an abortion of an "increased risk of suicide ideation and suicide," violated practitioners' First Amendment rights and unduly burdened access to abortion. ${ }^{121}$ And in 2014, the Eleventh Circuit vacated an injunction against a Florida law restricting practitioners' ability to communicate with patients about gun ownership because "it is uncontroversial that a state

115. See Dent, 129 U.S. at 121; see also Jost, supra note 30, at 827 (explaining Dent's argument).

116. See Dent, 129 U.S. at 121

117. Id. at $121-22$.

118. See, e.g., Noah, supra note 25 , at 159

119. See Minnesota ex rel. Whipple v. Martinson, 256 U.S. 41, 45 (1921).

120. Vacco v. Quill, 521 U.S. 793, 796-97 (1997) (holding that New York's law does not violate the Equal Protection Clause); Washington v. Glucksberg, 521 U.S. 702, 705-06 (1997) (holding that Washington's law does not violate the Due Process Clause).

121. Planned Parenthood v. Rounds, 686 F.3d 889, 897 (8th Cir. 2012). A number of other state medical practice laws that have been challenged-and upheld-also concern abortion practices. See, e.g., Erin Bernstein, The Upside of Abortion Disclosure Laws, 24 STAN. L. \& POL'Y REV. 171, 180-86 (2013); infra note 125 and accompanying text; $c f$. Guttmacher Inst., An Overview of Abortion Laws, ST. POLICIES IN BRIEF, May 1, 2015, available at http://www.guttmacher.org/statecenter/spibs/spib_OAL.pdf [http://perma.cc/ 4RKN-V6QQ] (describing the range of state abortion laws that are in effect). 
may police the boundaries of good medical practice" and "[a]ny burden the Act places on physician speech is [ ] entirely incidental."

This is not to say that states' authority to regulate medical practice is limitless. As an example, recently courts have struck down a few state laws restricting the off-label use of abortion-inducing drugs on the basis that the laws violate patients' constitutional rights. In 2013, the Oklahoma Supreme Court determined that an Oklahoma law prohibiting off-label use of abortion-inducing drugs unduly burdened abortion access, ${ }^{123}$ and in 2014 the Ninth Circuit ordered the district court to enjoin a similar Arizona law. ${ }^{124}$ But courts also have rejected arguments that comparable Ohio and Texas laws unduly burden abortion access in violation of the Fourteenth Amendment. ${ }^{125}$ Moreover, that there are relatively few cases striking down state medical practice laws illustrates that the limits on states' authority are few and far between. ${ }^{126}$

\section{Carrying Out State Regulation}

States exercise their far-reaching authority to regulate medical practice in a number of ways. Most importantly, states regulate medical practice by defining what falls within the scope of medical practice and requiring

122. Wollschlaeger v. Governor of Fla., 760 F.3d 1195, 1203 (11th Cir. 2014). But see Wollschlaeger v. Farmer, 880 F. Supp. 2d 1251, 1255, 1270 (S.D. Fla. 2012) (enjoining the law on the grounds that it violated practitioners' First and Fourteenth Amendments rights).

123. See Okla. Coal. for Reprod. Justice v. Cline, 2012 OK 102, \ 3, 292 P.3d 27, 27-28. Oklahoma's law, unlike other similar state laws, required on-label use of all abortioninducing drugs without exception. This effectively prohibited non-surgical abortions because the label for mifepristone, the only drug that is FDA-approved for terminating an intrauterine pregnancy, states that two days after patients take mifepristone, they "must take" another drug, misoprostol. Mifeprex (Mifepristone) Label, available at http://www. accessdata.fda.gov/drugsatfda_docs/label/2004/020687s010-lbl.pdf [http://perma.cc/8BNZ8J9Y]. However, while misoprostol can cause abortions, it is not FDA-approved for that purpose. See Cytotec (Misoprostol) Label, available at http://www.accessdata.fda.gov/ drugsatfda_docs/label/2012/019268s047lbl.pdf [http://perma.cc/S78U-D96M]. Thus, it is impossible to use all abortion-inducing drugs on label, and requiring the on-label use of all abortion-inducing drugs without exception de facto prohibits the use of any abortioninducing drugs.

124. See Planned Parenthood Ariz., Inc. v. Humble, 753 F.3d 905, 918 (9th Cir. 2014).

125. See Planned Parenthood Sw. Ohio Region v. DeWine, 696 F.3d 490, 496 (6th Cir. 2012); Planned Parenthood Tex. v. Abbott, 748 F.3d 583, 605 (5th Cir. 2014).

126. Cf. Noah, supra note 25 , at 159 (" $[\mathrm{N}]$ o one today seriously doubts the proposition that the states enjoy the authority to adopt reasonable restrictions designed to promote the public health."). 
that those practicing medicine be licensed. ${ }^{127}$ Although which specific activities constitute medical practice vary by state, each state generally defines medical practice quite broadly. Medical practice generally includes activities such as diagnosing and treating disease and conditions, as well as, in some cases holding oneself out as a medical practitioner, testifying as an expert witness, or reviewing claims for insurance companies. ${ }^{128}$ By 1895 , all of the existing states had required that anyone practicing medicine be licensed, and had established state boards to oversee those requirements. ${ }^{129}$ This continues today - all fifty states have boards that are responsible for licensing medical practitioners. ${ }^{130}$ The basic requirements for obtaining a medical license are consistent across states, and for physicians, include graduating from an accredited medical school, completing at least one year of a residency or fellowship, and passing a licensing examination. ${ }^{131}$ Beyond these basic requirements there is variation, with some states also requiring, among other things, interviews, a documented lack of a criminal history, and proof of malpractice insurance coverage. ${ }^{132}$ In addition to granting licenses, state boards are authorized to discipline licensees. ${ }^{133}$ Depending on the state, gross incompetence, physical or mental impairment, substance abuse, and aiding in the unauthorized practice of medicine, among other

127. See, e.g., Robert I. Field, HeAlth CARE Regulation in AmERica: CompleXity, CONFRONTATION, AND COMPROMise 19 (2007) [hereinafter Field, Health CARE REgUlation] (noting that the "cornerstone" of medical practice regulation is states' licensing schemes).

128. See supra notes $34-43$ and accompanying text.

129. See DERBYSHIRE, supra note 29 , at 8.

130. See, e.g., Directory of State Medical and Osteopathic Boards, FED'N OF ST. MED. BOARDS, http://www.fsmb.org/state-medical-boards/contacts [http://perma.cc/GUW3C596] (last visited Feb. 18, 2015); Boards of Pharmacy, NAT'L Ass'N OF BOARDS OF PHARMACY, https://www.nabp.net/boards-of-pharmacy [https://perma.cc/ D7JG-ZDDA]; State Boards, AM. ASS'N OF DENTAL BOARDS, http://www.dentalboards.org/states/index.htm [http://perma.cc/BCV9-QJFX]. The Supreme Court's recent decision in North Carolina State Board of Dental Examiners vs. FTC, discussed in section II.B.2, may lead to some changes in the composition of these boards or in how they operate. But the decision does not mean that states generally cannot use such boards to oversee medical practice. See N.C. State Bd. of Dental Exam'rs v. FTC, 135 S. Ct. 1101 (2015).

131. See, e.g., Nadia N. Sawicki, Character, Competence, and the Principles of Medical Discipline, 13 J. Health CARE L. \& Pol'y 285, 290 (2010); Janet M. Torpy et al., Medical Licensure, 304 JAMA 1286, 1286 (2010); Robert Kocher et al., Doctors Without State Borders: Practicing Across State Lines, Health Aff. Blog (Feb. 18, 2014), http://healthaffairs.org/blog/2014/02/18/doctors-without-state-borders-practicing-acrossstate-lines/ [http://perma.cc/4NYV-ESQQ].

132. See, e.g., Sawicki, supra note 131, at 291-92; Kocher et al., supra note 131.

133. See, e.g., Timothy S. Jost et al., Consumers, Complaints, and Professional Discipline: A Look at Medical Licensure Boards, 3 HeALTH MATRIX 309, 326-30 (1993). In some cases, state boards also might take actions to prevent unlicensed individuals from practicing medicine. See, e.g., N.C. State Bd. of Dental Exam'rs, 135 S. Ct. at 1108. 
things, are grounds for discipline. ${ }^{134}$ Disciplinary actions range from minor reprimands to limiting, suspending, or revoking a license. ${ }^{135}$

Although defining the scope of medical practice, licensing requirements, and medical board disciplinary actions are the primary ways that states regulate medical practice, there are a number of other ways in which states exert their authority to oversee medicine. As an example, states have enacted laws and regulations that directly circumscribe how licensed practitioners conduct medical practice. As discussed in section II.C.1. above, some states have enacted laws that regulate controversial areas of medical practice, such as physician-assisted suicide and abortion. ${ }^{136}$ State laws and regulations, however, are not limited to these contentious areas. For instance, every state requires that medical practitioners report certain infectious diseases to the state. ${ }^{137}$ In addition, most states have enacted laws or regulations that encourage a pharmacy to substitute a generic drug when a physician prescribes a brand-name drug — essentially overriding a physician's recommendation for a brand-name drug. ${ }^{138}$ As a corollary to the drug substitution laws, twenty-nine states have laws requiring that pharmacists provide certain information to patients when dispensing a generic drug that has been substituted for a brand-name drug. ${ }^{139}$ Some

134. See, e.g., Sawicki, supra note 131, at 291-92.

135. See Jost et al., supra note 133, at 326-31; see, e.g., OHIO REv. Code AnN. § 4731.22 (LexisNexis 2006) ("The state medical board . . . may limit, revoke, or suspend an individual's certificate to practice, refuse to grant a certificate to an individual, refuse to register an individual, refuse to reinstate a certificate, or reprimand or place on probation the holder of a certificate ....").

136. See supra notes 120-24 and accompanying text.

137. See Reportable Diseases, MEDLINEPLus, http://www.nlm.nih.gov/medlineplus/ ency/article/001929.htm [http://perma.cc/K7C2-SXB6] (last updated May 19, 2013); see, e.g., Cal. Health \& Safety Code $\S 120130$ (West 2012) (stating that the California public health department is required to establish a list of reportable diseases).

138. See Orange Book Preface, FDA, http://www.fda.gov/drugs/developmentapproval process/ucm079068.htm [http://perma.cc/D2RX-QSKD] (last updated Mar. 14, 2014); see, e.g., CONN. GEN. STAT. ANN. § 20-619(b) (West 2008) ("[U]nless the purchaser instructs otherwise, the pharmacist may substitute a generic drug product . . .."); DEL. CODE ANN. tit. 24, § 2549(a) (2011) (specifying the conditions under which a pharmacist may substitute a generic drug).

139. See Sarah Lichtman Spector \& Mara Youdelman, Nat'l Health LaW Program, Analysis of State Pharmacy Laws: Impact of Pharmacy Laws on the Provision OF LANGUAGE SERVICES 23-75 (2010), available at http://www.healthlaw.org/ about/staff/mara-youdelman/all-publications/analysis-of-state-pharmacy-laws-impact-ofstate-pharmacy-laws-on-the-provision-of-language-services\#.VWvMTs9VhBc [http://perma.cc/ A3AS-DMWN]. 
states require that certain information be provided to patients about various conditions or treatments. California, for example, requires that physicians distribute standardized pamphlets to patients about blood transfusions, breast cancer, gynecological cancers, silicone implants, prostate cancer, and patients' rights and remedies when they have been sexually involved with their therapist. ${ }^{140}$ States also require that certain procedures be performed within specific, but varying, timeframes. New Hampshire, Michigan, and Massachusetts require that infants be treated with eye drops immediately, within one hour, or within two hours after birth, respectively. ${ }^{141}$ Similarly, every state requires that medical practitioners perform certain tests to screen newborns for genetic or metabolic disorders, although what tests must be performed differs among the states. ${ }^{142}$ State legislators in New York even proposed establishing a dress code for medical practitioners. ${ }^{143}$

In addition to these state laws and statutes, medical malpractice liability - a creature of state law-provides a mechanism for private enforcement of medical practice standards. ${ }^{144}$ In general, medical practitioners are liable for harm caused by care that deviates from the professional standard. ${ }^{145}$ In addition to making the injured patient "whole" through compensation, one purpose of holding medical practitioners liable for such care is to reduce injuries by deterring substandard care. ${ }^{146}$ While there is

140. Med. Bd. of CAL., Guide to the Laws Governing the Practice of Medicine By Physicians AND SuRgeOns 70-71 (7th ed. 2013), available at http://www.mbc.ca.gov/ About_Us/Laws/laws_guide.pdf [http://perma.cc/K3WB-YHSK].

141. N.H. Rev. Stat. AnN. § 132:6 (2006); Mich. ComP. LAws ANN. § 333.5125 (West 2001); MASS. GEN. LAWS ANN. ch. 111, § 109A (West 2003). Newborns are treated with drops to prevent eye infections, such as gonorrhea or chlamydia that can be contracted during delivery if the mother is infected. Your Baby's First Hours of Life, WOMENSHEALTH.GOV (Sept. 27, 2010), http://www.womenshealth.gov/pregnancy/childbirthbeyond/baby-first-hours.html [http://perma.cc/J5AT-FM23].

142. About Newborn Screening: Conditions Screened by State, BABY'S FIRST TEST, http://www.babysfirsttest.org/newborn-screening/states [http://perma.cc/9RNC-BG4H] (last visited Feb. 18, 2015); see also Jennifer Kraszewski et al., Legal Issues in Newborn Screening: Implications for Public Health Practice and Policy, 121 PuB. HeAlth ReP. 92, 92-93 (2006), available at http://www.publichealthreports.org/issueopen.cfm?articleID $=1585$ [http://perma.cc/QMF9-GY63] (discussing the legal issues raised by state newborn screening programs).

143. S.B. 4909, 2011-2012 Reg. Sess. (N.Y. 2011), available at http://open.nysenate. gov/legislation/bill/S4909-2011 [http://perma.cc/E68L-P2TW].

144. See, e.g., Robert L. Rabin, Federalism and the Tort System, 50 RuTGERs L. REV. 1, 2 (1997). Although medical malpractice was traditionally a common law doctrine, a number of states have enacted statutes that govern aspects of medical malpractice claims, such as caps on damages. See id. at 3-4.

145. See, e.g., Theodore Silver, One Hundred Years of Harmful Error: The Historical Jurisprudence of Medical Malpractice, 1992 WIS. L. REV. 1193, 1212 (1992).

146. See, e.g., Michelle M. Mello et al., National Costs of the Medical Liability System, 29 HeAlth AfF. 1569, 1570 (2010). 
no reliable empirical evidence that malpractice liability actually accomplishes this goal, ${ }^{147}$ it nevertheless is another way in which states, rather than the federal government, regulate medical practice.

Lastly, states historically have relied on professional organizations to police many areas of medical practice. ${ }^{148}$ While such self-regulation is not as pervasive as it once was, ${ }^{149}$ certain domains of self-regulation persist. For example, with limited exceptions, ${ }^{150}$ states generally do not restrict practitioners' off-label prescribing; instead, professional organizations have issued policies describing when off-label use is appropriate. ${ }^{151}$ Additionally, before the Supreme Court's decision in North Carolina State Board of Dental Examiners vs. FTC discussed in section II.B.2., some scholars argued that, because medical practitioners generally comprise a majority of the members of state medical boards, practitioners effectively govern their own licensure and discipline. ${ }^{152}$ It is not yet clear how, or whether, North Carolina State Board of Dental Examiners will change the composition of state boards, or how they operate. ${ }^{153}$ Nevertheless, delegating oversight to the medical profession itself is another way states oversee-or decline to oversee-medical practice.

147. See id.; Michelle M. Mello \& Troyen A. Brennan, Deterrence of Medical Errors: Theory and Evidence for Malpractice Reform, 80 TEX. L. REV. 1595, 1606-15 (2002). This is not to say that medical malpractice liability serves no purpose. In addition to compensating injured patients, scholars have argued that malpractice liability brings medical errors to light, and in certain specialties, has improved patient safety. See, e.g., TOM BAKER, THE MEDICAL MALPRACTICE MYTH 93-117 (2005).

148. See Field, Health Care Regulation, supra note 127, at 24-28; Robert I.

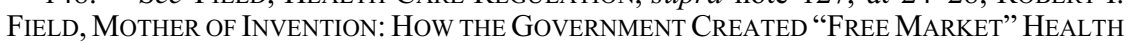
CARE 122-30 (2013) [hereinafter FIELD, MOTHER OF INVENTION]; STARR, supra note 30, at 24-28; Malinowski, supra note 71, at 1091-99.

149. See, e.g., Scott Gottlieb, How American Doctors Lost Their Professional Autonomy, FORBES (May 16, 2014, 8:24 AM), http://www.forbes.com/sites/scottgottlieb/ 2014/05/16/how-american-doctors-lost-their-professional-autonomy/ [http://perma.cc/B8MLH7RR].

150. See supra notes 123-23 and accompanying text for a discussion of state laws restricting off-label use of abortion-inducing drugs.

151. See, e.g., Dresser \& Frader, supra note 45, at 479.

152. See, e.g., M. Christine Cagle et al., Privatizing Professional Licensing Boards: Self-Governance or Self-Interest?, 30 ADMIN. \& SoC'Y 734, 750-51 (1999).

153. See, e.g., Lisa Schencker, Supreme Court Ruling Carries Implications for Regulatory Boards, Modern Healthcare (Feb. 25, 2015), http://www.modernhealthcare. $\mathrm{com} /$ article/20150225/NEWS/150229950/supreme-court-ruling-carries-implications-forregulatory-boardsl [http://perma.cc/PX5C-3TZJ]; see also N.C. State Bd. of Dental Exam'rs v. FTC, 135 S. Ct. 1101, 1123 (2015) (Alito, J., dissenting) ("[I]t is not clear what sorts of changes [to boards] are needed to satisfy the test that [the majority] now adopts."). 


\section{Challenging the CONVEntional WisDom}

As the previous section demonstrates, the states extensively regulate medical practice - but, as this section shows, the federal government also plays a substantial, although haphazard and at times opaque, role in controlling medical practice, both directly and indirectly. ${ }^{154}$

\section{A. Examples of Federal Regulation}

This section synthesizes the evidence challenging the conventional wisdom to show that there are multiple circumstances in which the federal government oversees medical practice. From wide-ranging oversight, such as regulating the use of controlled substances, ${ }^{155}$ influencing medical decision-making through Medicare payment policies ${ }^{156}$ and the PPACA's incentives for improving the quality of medical care, ${ }^{157}$ to narrower instances of oversight such as the federal ban on off-label use of Human Growth Hormone, ${ }^{158}$ the federal government exercises an enormous amount of control over certain areas of medicine. Although by no means exhaustive, ${ }^{159}$ the following examples of direct and indirect federal regulation of medical

154. Cf. Lawrence Lessig, The New Chicago School, 27 J. Legal Stud. 661, 662 (1998) (describing, in general but not in the medicine context, both direct and indirect forms of regulation).

155. See supra notes 160-62 and accompanying text; infra notes $154-74$ and accompanying text.

156. See infra notes 214-31 and accompanying text.

157. See Patient Protection and Affordable Care Act, Pub. L. No. 111-148, § 1501(a), 124 Stat. 119, 242-44 (2010); Robert Kocher et al., The Affordable Care Act and the Future of Clinical Medicine: The Opportunities and Challenges, 153 AnNALs of INTERNAL MED. 536, 536-37 (2010).

158. See infra notes 174-75 and accompanying text.

159. For instance, the Emergency Medical Treatment and Labor Act (EMTALA) is a federal law that influences medical practice that is not discussed in depth in this section. In short, EMTALA requires hospitals that participate in Medicare and offer emergency services to provide treatment and stabilizing care to patients with emergency medical conditions, regardless of their ability to pay. Ctrs. for Medicare and Medicaid Servs., Emergency Medical Treatment \& Labor Act (EMTALA), CMS.gOv, http://www.cms. gov/Regulations-and-Guidance/Legislation/EMTALA/index.html?redirect=/EMTALA/ [http:// perma.cc/8A74-AN9B] (last modified Mar. 26, 2012). The PPACA's incentives for practitioners and hospitals to improve the quality of medical care, the application of the Americans with Disabilities Act to dentists' decisions about which patients to treat, and the national coordination of physician discipline through the Health Care Quality Improvement Act of 1986 are additional examples of federal influence over medical practice that are not discussed in depth in this section. See Patient Protection and Affordable Care Act $\S 1501$ (b) (providing incentives for practitioners and hospitals to improve quality of care); Bragdon v. Abbott, 524 U.S. 624, 641 (1998) (holding that HIV infection is a disability within the meaning of the Americans with Disabilities Act, in a case involving dental care); Field, Health CARE Regulation, supra note 127, at 31-32 (describing the Health Care Quality Improvement Act). 
practice illustrate the many ways that the federal government regulates medicine.

\section{Direct Regulation}

The following are examples of direct federal regulation of medical practice - where the federal government explicitly restricts practitioners' behavior, and practitioners can be penalized for failing to comply with such restrictions.

\section{a. The Controlled Substances Act}

The Controlled Substances Act of 1970 (CSA) is one example of direct federal regulation of medical practice. ${ }^{160}$ The CSA authorizes the federal government to regulate controlled substances, which include FDAapproved drugs that are associated with a risk of addiction or abuse. ${ }^{161}$ Under the CSA, the federal government directly regulates medical practice in two ways: (1) it restricts how controlled substances are used in medical practice; and (2) it dictates which practitioners may use controlled substances.

First, the use of a controlled substance is restricted based on which of five "schedules" the drug falls into. Controlled substances are categorized into these five schedules depending on their potential for abuse, accepted medical uses, and safety, with substances in Schedule I subject to the most severe restrictions and substances in Schedule V subject to the least severe. $^{162}$ Because drugs in Schedule I are deemed to have no accepted medical uses, practitioners may not prescribe, dispense, or distribute them. ${ }^{163}$

160. See Comprehensive Drug Abuse Prevention and Control Act of 1970, Pub. L. No. 91-513, §§ 100-411, 84 Stat. 1236, 1242-84 (1970).

161. See 21 U.S.C. $\$ \S 802(6), 811(\mathrm{c}), 812$ (2012); see also Aaron Gilson \& Ben A. Rich, Legal and Regulatory Issues in Pain Management, in EsSENTIALS OF PAIN MEDICINE (Honorio Benzon et al. eds., 3d ed. 2001). Certain controlled substances, such as extended-release and long-acting opioids, are also subject to FDA-required Risk Evaluation and Mitigation Strategies that indirectly control how medical practitioners may use those drugs. See discussion infra section III.A.2.b.

162. See 21 U.S.C. $\$ 812$ (b) (2012); U.S. DeP’T OF Justice, Drug ENFORCEMENT ADMIN., OfFICE OF Diversion CONTROL, Practitioner's MANUAL 5-6 (2006) [hereinafter DEA MANUAL], available at http://www.deadiversion.usdoj.gov/pubs/manuals/pract/pract _manual012508.pdf [http://perma.cc/8295-BAPY].

163. See 21 U.S.C. $\S 812$ (b)(1) (2012); DEA MANUAL, supra note 162, at 5. For example, because marijuana is a Schedule I drug, practitioners violate federal law if they choose to treat their patients with marijuana, even if state law permits it. $C f$. Gonzales v. Raich, 545 U.S. 1, 33 (2005) (holding that the CSA applied to patients' intrastate use of 
Drugs in Schedules II through V may be used in medical practice, but their use is limited. For example, for Schedule II drugs, such as hydrocodone, ${ }^{164}$ practitioners must provide written prescriptions for the drugs - they may not provide oral prescriptions over the phone - and no refills are permitted. ${ }^{165}$ Also, drugs in Schedules II through V may not be prescribed for "detoxification treatment" or "maintenance treatment" unless the FDA has approved them for that use. ${ }^{166}$

Second, under the CSA, the federal government controls who may use controlled substances in their medical practice. ${ }^{167}$ In order to prescribe, distribute, or dispense controlled substances in Schedules II through V, practitioners must register with the Drug Enforcement Administration (DEA), the agency primarily responsible for enforcing the CSA. ${ }^{168}$ The DEA may refuse to register a practitioner if it determines that registering the practitioner "would be inconsistent with the public interest."169 Furthermore, if practitioners are convicted of an offense under the CSA punishable by more than one year in prison, the federal government may order them to forfeit their state-issued medical license. ${ }^{170}$

Because the CSA authorizes the federal government to govern the use of controlled substances and which medical practitioners may use them, it is unsurprising that the legislative history and cases concerning the CSA, discuss its impact on medical practice. In hearings before a Senate Subcommittee prior to the CSA's enactment, the American Psychiatric Association expressed concern that these "enforcement authorities seemed to

medical marijuana permitted under California law). That said, the federal government has chosen to limit its enforcement of federal prohibitions on marijuana in certain circumstances. See Memorandum from James M. Cole, Deputy Attorney Gen., U.S. Dep't of Justice, to All U.S. Attorneys, on Guidance Regarding Marijuana Enforcement (Aug. 29, 2013), available at http://www.justice.gov/iso/opa/resources/3052013829132756857467.pdf [http:// perma.cc/F8U9-CVSD].

164. Hydrocodone is an opioid found in many drugs that are approved for pain relief; fixed-dose combinations of hydrocodone and acetaminophen - the active ingredient in Tylenol-are some of the most widely used drugs in the United States. Although drugs containing hydrocodone as their sole active ingredient have long been in Schedule II, the DEA recently moved the fixed-dose combinations of hydrocodone and acetaminophen to Schedule II as well. See Schedules of Controlled Substances: Rescheduling of Hydrocodone Combination Products from Schedule III to Schedule II, 79 Fed. Reg. 49,661, 49,662, 49,675 (Aug. 22, 2014) (to be codified at 21 C.F.R. pt. 1308), available at http://www.gpo. gov/fdsys/pkg/FR-2014-08-22/pdf/2014-19922.pdf [http://perma.cc/4D7G-NUSJ].

165. See 21 U.S.C. $\$ 829$ (a) (2012).

166. 21 C.F.R. $\$ 1306.04(\mathrm{c})(2014)$.

167. See 21 U.S.C. $\S \S 802(10), 823$ (2012); DEA MANUAL, supra note 162, at 4, 7.

168. See DEA MANUAL, supra note 162, at 7.

169. 21 U.S.C. $\$ 823(\mathrm{f})(2012)$.

170. See 21 U.S.C. $§ 853$ (2012); United States v. Singh, 390 F.3d 168, 190 (2d Cir. 2004). 
be dictating the practice of medicine." ${ }^{\prime 17}$ Additionally, although courts have generally rejected arguments that the CSA impermissibly regulates medical practice, ${ }^{172}$ the Supreme Court has acknowledged that the CSA regulates medical practice, at least in a limited way. In Gonzales v. Oregon, the Court explained that "Congress regulates medical practice insofar as it bars doctors from using their prescription-writing powers as a means to engage in illicit drug dealing and trafficking," but also that the CSA "manifests no intent to regulate the practice of medicine generally ...."."173 However, because controlled substances include some of the most widely used drugs in the United States, ${ }^{174}$ the CSA's impact on medicine is, in practice, quite extensive.

\section{b. Use of Human Growth Hormone}

Another example of direct federal regulation involves drugs containing Human Growth Hormone (HGH). For most prescription drugs, once they receive FDA approval, a practitioner may prescribe, dispense, or administer them for any use, including off-label uses. ${ }^{175}$ This, however, is not the case for HGH. Section 303(e) of the Federal Food, Drug, and Cosmetic Act (FDCA) prohibits knowingly prescribing, dispensing, or administering HGH for anything other than its FDA-approved uses. ${ }^{176}$ Human Growth Hormone is approved for a variety of indications, including the treatment of children with short stature and adults with growth hormone deficiency, ${ }^{177}$

171. Federal Drug Abuse and Drug Dependence Prevention, Treatment, and Rehabilitation Act of 1970: Hearing on S. 3562 Before the Special Subcomm. on Alcoholism \& Narcotics of the S. Comm. on Labor \& Pub. Welfare, 91st Cong. 248 (1970) [hereinafter 1970 CSA Senate Hearing].

172. See, e.g., Singh, 390 F.3d at 190.

173. Gonzales v. Oregon, 546 U.S. 243, 269-70 (2006).

174. See Schedules of Controlled Substances: Rescheduling of Hydrocodone Combination Products From Schedule III to Schedule II, 79 Fed. Reg. 49,661, 49,675 (Aug. 22, 2014) (to be codified at 21 C.F.R. pt. 1308), available at http://www.gpo.gov/ fdsys/pkg/FR-2014-08-22/pdf/2014-19922.pdf [http://perma.cc/4D7G-NUSJ].

175. See, e.g., Dresser \& Frader, supra note 45, at 476. With the exception of HGH and the limits on prescribing controlled substances for detoxification and maintenance treatment, the federal government currently does not prohibit off-label prescribing and, with the exception of abortion-inducing drugs, states also have not restricted practitioners' discretion to prescribe off-label.

176. 21 U.S.C. $\$ 333($ e) (2012); Dresser \& Frader, supra note 45, at 477 n.11.

177. See, e.g., Humatrope, Label, http://www.accessdata.fda.gov/drugsatfda_docs/ label/2011/019640s084lbl.pdf [http://perma.cc/XKN2-Y23Y]; see also Thomas T. Perls et al., Provision or Distribution of Growth Hormone for Antiaging: Clinical and Legal 
but not the anti-aging and athletic performance-enhancing uses with which it is often associated. ${ }^{178}$

Interestingly, unlike the other examples of federal regulation described in this section, the addition of section 303(e) to the FDCA did not spark concerns about federal regulation of medical practice. Moreover, notwithstanding that this provision was added to the FDCA in $1990,{ }^{179}$ in 1997 Congress opined:

[I]t has been the long held view of Congress that the FDA should not regulate the practice of medicine. In general, the FDA has no authority to regulate how physicians prescribe approved drugs in the context of their medical practice. Physicians prescribing off-label uses of approved drugs is not within the jurisdiction of the FDA. 180

This failure to acknowledge section 303(e)'s effect on medical practice may arise from Congress's interest in the use of HGH to enhance athletic performance, rather than in its therapeutic uses. Congress added section 303(e) to the FDCA through the Anabolic Steroids Control Act of $1990 .^{181}$ The law was enacted after congressional hearings about widespread use of performance-enhancing drugs in sports, ${ }^{182}$ as well as several high profile athletic scandals, including a 1988 Sports Illustrated story reporting extensive steroid use in the University of South Carolina's football program that led to the indictment of four coaches. ${ }^{183}$ Consistent with this context,

Issues, 294 JAMA 2086, 2087 (2005) (summarizing the approved uses of various HGHcontaining drugs); S. Jay Olshansky \& Thomas T. Perls, New Developments in the Illegal Provision of Growth Hormone for "Anti-Aging" and Bodybuilding, 299 JAMA 2792, 2792 (2008) (describing approved adult indications for HGH-containing drugs).

178. See, e.g., Olshansky \& Perls, supra note 175, at 2792.

179. See United States Attorneys' Manual, Human Growth Hormone/Steroids Statutory Overview, OFFICES OF THE U.S. ATTORNEYS, http://www.justice.gov/usam/civilresource-manual-19-human-growth-hormonesteroids-statutory-overview [http://perma. cc/CV8Y-ZY6T] [hereinafter Manual, HGH/Steroids] (last visited May, 15, 2015).

180. H.R. REP. No. 105-310, at 60 (1997).

181. See Manual, HGH/Steroids, supra note 179. The Anabolic Steroids Control Act was enacted as Title XIX of the Crime Control Act of 1990. See Crime Control Act of 1990, Pub. L. No. 101-647, § 1904, 104 Stat 4851, 4853 (1990).

182. See Anabolic Steroid Control Act: Hearing on H.R. 4658 Before the Subcomm. on Crime of the H. Comm. on the Judiciary, 101st Cong. 8 (1990) (statement of Rep. William J. Hughes, Chairman, H. Subcomm. on Crime); Abuse of Steroids in Amateur and Professional Athletics: Hearing Before the Subcomm. on Crime of the H. Comm. on the Judiciary, 101st Cong. 2, 10 (1990) (statements of Rep. William J. Hughes, Chairman, H. Subcomm. on Crime \& Paul J. Tagliabue, NFL Comm'r); see also Steroids in Amateur and Professional Athletics: The Medical and Social Costs of Steroids Abuse: Hearing Before the S. Comm. on the Judiciary, 101st Cong. 179 (1989) (statement of Bill Fralic, NFL Player) (hearing in which witnesses testified to rampant steroid use in the NFL).

183. See Tommy Chalkin \& Rick Telander, The Nightmare of Steroids, SPORTS ILLUSTRATED (Oct. 24, 1988), http://www.si.com/vault/1988/10/24/118707/the-nightmare-ofsteroids-south-carolina-lineman-tommy-chaikin-used-bodybuilding-drugs-for-three-years- 
many of the criminal investigations and prosecutions brought under section 303(e) have involved practitioners providing HGH to athletes. ${ }^{184}$

\section{c. The Partial-Birth Abortion Ban Act}

The Partial-Birth Abortion Ban Act $^{185}$ is a third example of direct federal regulation. This federal law, enacted in 2003, prohibits physicians from knowingly performing a procedure that the law calls "partial-birth abortion." 186 The statute defines a partial-birth abortion as "an abortion in which the person performing the abortion ... deliberately and intentionally vaginally delivers a living fetus" until a certain portion of the fetus is outside the mother's body, and "performs the overt act, other than completion of delivery, that kills the partially delivered living fetus." 187 As interpreted by the Supreme Court in Gonzales v. Carhart, the case upholding the law, this language prohibits physicians from intentionally performing one particular abortion procedure: "intact dilation and evacuation."188

Congress clearly intended to directly regulate medical practice by prohibiting this procedure. In upholding the law, the Supreme Court noted, "the legislative power [was] exercised in this instance . . . to regulate the medical profession." 189 Consistent with the Court's view, the medical profession perceived this law as interfering with medical practice. For example, the American College of Obstetricians and Gynecologists (ACOG), which is "the leading professional association of physicians who specialize in the health care of women," argued said that the law "will

they-drove-him-to-violence-and-nearly-to-suicide [http://perma.cc/GC8Z-S6FZ]; 4 ExFootball Aides Indicted in South Carolina Steroid Case, N.Y. Times, Apr. 20, 1989, http://www.nytimes.com/1989/04/20/sports/4-ex-football-aides-indicted-in-south-carolinasteroid-case.html [http://perma.cc/QNE3-YWKZ].

184. See, e.g., Press Release, U.S. Dep't of Justice, Powermedica Defendants Sentenced for Conspiracy to Illegally Distribute Human Growth Hormones and Steroids (Apr. 20, 2011), available at http://www.fda.gov/ICECI/CriminalInvestigations/ucm 252 150.htm [http://perma.cc/L8WD-2JYT]; Press Release, U.S. Dep't of Justice, Colorado Springs Pharmacists Convicted of Charges Related to Importation and Distribution of Anabolic Steroids and Chinese-Made Human Growth Hormones (Jan. 2, 2010), available at http://www.fda.gov/ICECI/CriminalInvestigations/ucm200282.htm [http://perma.cc/92 MF-687S].

185. See Partial-Birth Abortion Ban Act of 2003, Pub. L. No. 108-105, 117 Stat. 1201 (2003).

186. See 18 U.S.C. $§ 1531$ (a) (2012).

187. Id. $\S 1531(\mathrm{~b})(1)$.

188. Gonzales v. Carhart, 550 U.S. 124, 154-56 (2007).

189. Id. at 166. 
chill doctors from providing a wide range of procedures used to perform induced abortions or to treat cases of miscarriage."190

\section{Indirect Regulation}

The following examples illustrate indirect regulation of medical practice - that is, they are examples of federal requirements that do not apply to practitioners and practitioners do not incur penalties when the requirements are violated but, nevertheless, they affect medical practice.

\section{a. FDA's Pre-Market Authorization of Drugs, Devices, and Biologics}

Although courts, Congress, and the FDA have attempted to draw a firm line between what constitutes regulating medical practice versus medical products, ${ }^{191}$ the FDA's review of medical products-drugs, devices, and biologics - before they enter the market offers one of the most sweeping examples of how the federal government indirectly regulates medical practice. In general, drugs, biologics, and medical devices cannot be used for medical treatment in the United States until the FDA determines that they are safe and effective. ${ }^{192}$ Although medical product manufacturers and sellers, rather than practitioners, typically incur penalties for marketing unapproved medical products, ${ }^{193}$ medical practitioners' options for treating their patients are limited by the FDA's judgment about what products are

190. Brief of the American College of Obstetricians and Gynecologists as Amicus Curiae Supporting Respondents, Gonzales v. Carhart, 550 U.S. 124 (2007) (Nos. 05-380, 1382), 2006 WL 2867888, at *1, *22; Am. Cong. Of Obstetricians \& Gynecologists, ACOG Statement on the US Supreme Court Decision Upholding the Partial-Birth Abortion Ban Act of 2003, ACOG (Apr. 18, 2007), http://www.acog.org/About_ACOG/ News_Room/News_Releases/2007/ACOG_Statement_on_the_US_Supreme_Court_Dec ision [http://perma.cc/6YYN-F79U].

191. See, e.g., supra notes 9-10 and accompanying text; see also CLEMENT \& TRIBE, supra note 60, at 11 (arguing that the FDA lacks authority over certain diagnostics because they constitute medical practice, rather than medical products).

192. See 21 U.S.C. $\S \S 355(d), 360$ c(i), 360e (2012); 42 U.S.C. $\S 262(a)(2)$ (B) (2012). There are some medical products that may be sold without FDA approval. For example, drugs that are "generally recognized . . . as safe and effective" and have been used "to a material extent" and "for a material time" may be marketed without FDA approval. See 21 U.S.C. $\S \S 321($ p), 355(a) (2012).

193. The Federal Food, Drug, and Cosmetic Act prohibits a number of activities, such as introducing an unapproved drug or device into interstate commerce, that entities which make and sell medical products, rather than practitioners, are likely to violate. See 21 U.S.C. § 331 (2012); but see United States v. Regenerative Scis., LLC, 741 F.3d 1314, 1326 (D.C. Cir. 2014) (affirming an injunction against practitioners who provided autologous stem cell treatments in violation of the FDCA). 
safe and effective. ${ }^{194}$ That is, the FDA indirectly regulates medical practice by determining which medical products may be sold, and thus, used, by medical practitioners, in the United States.

Indeed, throughout the FDA's history, concerns have been raised that the FDA's role as gatekeeper of medical products is tantamount to the regulation of medical practice. For example, when Congress amended the FDCA in 1962 to require that a drug's effectiveness be demonstrated before marketing, the AMA opposed the amendments on the ground that the FDA's effectiveness determinations about drugs would interfere with physicians' ability to provide treatments in their patients' best interests. ${ }^{195}$ In a Senate hearing on the 1962 amendments, an AMA spokesperson asserted, "only the individual physician [can] determine the efficacy of a given drug in the treatment of a given patient."196 Likewise, one Newsweek columnist argued "[i]t is a dangerous legal precedent to allow any bureaucrat to keep off the market something that, even though harmless, is in his opinion 'ineffective.' This is trying to protect the patient against the judgment of his doctor." 197 When amendments to the FDA's regulatory scheme for devices were enacted in 1997, Congress included language protecting practitioners' discretion to prescribe and administer legally marketed devices off-label, presumably to address concerns about the FDA interfering with medical practice. ${ }^{198}$ Moreover, the notion that authorizing the FDA to evaluate the effectiveness of medical products is "dangerous" for patients persists today, particularly in the context of terminally ill patients' access

194. Because the FDA's statutory authority is linked to the movement of a product or its components through interstate commerce, theoretically, there may be some medical products produced and used wholly intrastate that would not be subject to the FDA's oversight. It is difficult, however, to conceive of a modern medical product, except perhaps medical marijuana, that does not travel in interstate commerce such that the FDA would not have jurisdiction over it. Cf. Regenerative Scis., 741 F.3d at 1326 (affirming the FDA's jurisdiction over autologous stem cell treatments); but see Epstein, supra note 10 , at 1-2 (arguing that the FDA's statutory authority does not extend to the autologous stem cell treatments at issue in Regenerative Sciences).

195. See Drug Amendments of 1962, Pub. L. No. 87-781, § 102(c), 76 Stat. 780, 781 (1962); HiLTS, supra note 53, at 139-40.

196. Richard Harris, The Annals of Legislation: The Real Voice-II, THE NEW YORKER, Mar. 21, 1964, at 146 [hereinafter Harris, The Real Voice-II].

197. HILTS, supra note 53, at 140.

198. See Food and Drug Administration Modernization Act of 1997, Pub. L. No. 105-115, § 214, 111 Stat. 2296, 2348 (1997) (codified at 21 U.S.C. § 396); Noah, supra note 25 , at 166 . 
to unapproved therapies. ${ }^{199}$ While the language of its enabling statute may prevent the FDA from restricting off-label use of medical devices, it nevertheless indirectly regulates medical practice by determining which therapeutic products may be used in medical practice.

\section{b. FDA-Required Risk Evaluation and Mitigation Strategies}

The FDA's drug safety authority provides another example of how the agency indirectly regulates medical practice. The Food and Drug Administration Amendments Act of 2007 (FDAAA) ${ }^{200}$ significantly strengthened the FDA's drug safety authority by, among other things, authorizing it to require Risk Evaluation and Mitigation Strategies (REMS) for certain drugs. ${ }^{201}$ The FDA can require a REMS for a prescription drug when the agency determines that a REMS is necessary to ensure that a drug's benefits outweigh its risks. ${ }^{202}$ Put simply, REMS impose requirements on a drug manufacturer that go beyond providing warnings and other information on a drug's label. ${ }^{203}$ Through a REMS, the FDA can require, among other things, that drug manufacturers undertake various "elements to

199. See, e.g., Christina Corieri, Everyone Deserves the Right to Try: Empowering the Terminally Ill to Take Control of Their Treatment, GOLDWATER INST. (Feb. 11, 2014), http:/goldwaterinstitute.org/en/work/topics/healthcare/right-to-try/everyone-deservesright-try-empowering-terminally-/ [http://perma.cc/7G4A-873W]; see also Patricia J. Zettler \& Henry T. Greely, The Strange Allure of State Right-to-Try Laws, 174 JAMA INTERNAL MED. 1885 (2014) (discussing the Right-to-Try movement at the state level); Seema K. Shah \& Patricia J. Zettler, From A Constitutional Right to A Policy of Exceptions: Abigail Alliance and the Future of Access to Experimental Therapy, 10 YALE J. HeAlth POL'Y L. \& ETHICS 135 (2010) (analyzing terminally ill patients' access to unapproved drugs in general).

200. Food and Drug Administration Amendments Act of 2007, Pub. L. No. 110-85, $\S \S 901-921,121$ Stat. 823, 922-62 (Sept. 27, 2007).

201. See 21 U.S.C. § 355-1(a) (2012); see also U.S. Food \& Drug AdMIn., DrafT GUIDANCE FOR INDUSTRY: FORMAT AND CONTENT OF PROPOSED RISK EVALUATION AND Mitigation Strategies (REMS), REMS Assessments, And Proposed REMS MODIFICATIONS (Sept. 2009) [hereinafter DRAFT REMS GUIDANCE], available at http://www.fda.gov/downloads/Drugs/Guidances/UCM184128.pdf [http://perma.cc/93 GU-R58Y] (describing the REMS provisions in FDAAA); Bruce M. Psaty \& David Korn, Congress Responds to the IOM Drug Safety Report-In Full, 298 JAMA 2185 (2007) ("FDAAA represents the most extensive revisions of the [FDCA] since 1962.").

202. See 21 U.S.C. § 355-1(a), (b). More specifically, the FDA can require REMS for prescription drugs, including controlled substances, that are submitted for approval or are already approved under a new drug application (NDA), an abbreviated-genericnew drug application (ANDA), or a biological license application (BLA).

203. See 21 U.S.C. § 355-1; DRAFT REMS GUIDANCE, supra note 201, at 2-7. REMS requirements apply to the person(s) who submit for approval covered NDAs, ANDAs, or BLAs, or who hold approved applications of these types. 21 U.S.C. $\S 355-$ 1(a). Because these persons are typically the drug's manufacturer, for simplicity this Article describes the REMS requirements as applying to a drug's manufacturer. 
assure safe use," such as ensuring that practitioners who prescribe or dispense the drug have special training, a drug is dispensed only in certain settings such as hospitals, or that certain test results are documented before a drug is dispensed. ${ }^{204}$

Isotretinoin - commonly known by its brand name, Accutane-is an example of a drug subject to a REMS that imposes some of these restrictions. $^{205}$ Isotretinoin is approved for the treatment of "severe recalcitrant nodular acne," but causes serious birth defects when taken by pregnant women and girls. ${ }^{206}$ Accordingly, the REMS for isotretinoin requires the drug's manufacturers to ensure that isotretinoin prescribers and dispensers are specially certified, and women and girls have two negative pregnancy tests documented nineteen days apart before a pharmacist dispenses the drug. ${ }^{207}$ To become certified, prescribers must agree to provide contraception counseling and pregnancy testing for women and girls, and pharmacies that dispense the drug must affirm that their pharmacists will dispense the drug only to REMS-qualified patients and dispense no more than a 30-day supply of the drug. ${ }^{208}$

The drug manufacturer is the entity ultimately responsible for ensuring that REMS requirements are met - meaning that the drug manufacturer, and not medical practitioners, will be the subject of any FDA enforcement actions that result from REMS violations. ${ }^{209}$ REMS requirements, however, do affect medical practice because practitioners are responsible for carrying out many of the elements to assure safe use. In some ways, REMS requirements' impact on medical practice is fairly limited because, of the approximately 22,000 approved brand-name and generic prescription

204. See 21 U.S.C. § 355-1(f)(3)(A), (C), (D).

205. See U.S. FoOd \& Drug Admin., Risk Evaluation and Mitigation Strategy (REMS), THE IPLEDGE PROGRAM, SINGLE SHARED SySTEM FOR ISOTRETINOIN (Apr. 2012), http://www.fda.gov/downloads/Drugs/DrugSafety/PostmarketDrugSafetyInformationfor PatientsandProviders/UCM234639.pdf [hereinafter IPLEDGE]. Accutane's manufacturer withdrew Accutane from the market in 2009, but numerous generic versions of the drug continue to be marketed. See Determination That ACCUTANE (Isotretinoin) Capsules, 10 Milligrams, 20 Milligrams, and 40 Milligrams, Were Not Withdrawn from Sale for Reasons of Safety or Effectiveness, 75 Fed. Reg. 39024, 39025 (July 7, 2010), available at http://www.gpo.gov/fdsys/pkg/FR-2010-07-07/pdf/2010-16439.pdf [http://perma.cc/CG P2-J6NU].

206. See, e.g., Absorbica, Label, available at http://www.accessdata.fda.gov/drugs atfda_docs/label/2012/021951s000lbl.pdf [http://perma.cc/X5CR-Z568].

207. See IPLEDGE, supra note 205.

208. Id.

209. See 21 U.S.C. $\S \S 333(f)(4)(A), 352(y), 355(p)(2012)$. 
drugs, ${ }^{210}$ only about 121 are subject to REMS that include elements to assure safe use. ${ }^{211}$ But when a drug is subject to a REMS that includes elements to assure safe use, how practitioners use that drug is significantly affected by tasks that they must perform, such as pregnancy testing and patient counseling in the case of isotretinoin. Discussions of the FDA's REMS authority have acknowledged this reality. The AMA, for example, has said that REMS "affect the daily practice of medicine," 212 and a pharmacist writing in Pharmacy Times argued that "REMS ha[ve] the potential to interfere with the practice of medicine." 213 Risk Evaluation and Mitigation Strategies thus provide an additional example of the FDA indirectly regulating medical practice.

\section{c. Medicare Coverage Levels and Covered Benefits}

Notwithstanding the first provision in the Medicare statute, which states "[n]othing in this [law] shall be construed to authorize any Federal officer or employee to exercise any supervision or control over the practice of medicine," 214 the coverage levels and covered benefits under Medicare offer a third example of indirect federal regulation of medical practice. ${ }^{215}$ Medicare is a government-funded insurance program for individuals sixtyfive years of age and older who qualify for Social Security retirement benefits. $^{216}$ In general, Medicare covers "items or services" that are

210. See, e.g., Development and Distribution of Patient Medication Information for Prescription Drugs; Public Hearing, 75 Fed. Reg. 52765, 52766 (Aug. 27, 2010), available at http://www.gpo.gov/fdsys/pkg/FR-2010-08-27/pdf/2010-21326.pdf [http://perma.cc/LH 7Z-LQNQ].

211. See Approved Risk Evaluation and Mitigation Strategies (REMS), FDA (May 19, 2014) [hereinafter List of Approved REMS], http://www.fda.gov/drugs/drugsafety/ postmarketdrugsafetyinformationforpatientsandproviders/ucm 111350.htm [http://perma.cc/E2 Z4-738T]. Although there are only about forty approved REMS with elements to assure safe use, each "single shared system" REMS applies to multiple drugs.

212. Am. Med. Ass'N, Report 8 of The Council on Science and Public Health Report, the Evolving Culture of Drug Safety in the United States: Risk EVALUATION AND Mitigation STRATEGIES (REMS) 1 (2010).

213. Darshan Kulkarni, Is REMS Interfering with the Practice of Medicine?, PHARMACY TIMES (Mar. 28, 2012), http://www.pharmacytimes.com/blogs/for-the-record/ 0312/Is-REMS-Interfering-With-the-Practice-of-Medicine [http://perma.cc/ANZ5-HRYV].

214. $\quad 42$ U.S.C. $§ 1395$ (2012).

215. See, e.g., FIELD, MOTHER OF InVENTION, supra note 148, at 132 (describing how Medicare transformed medical practice); Mark A. Hall, Law, Medicine, and Trust, 55 StAn. L. REV. 463, 501 n.151 (2002) ("Medicare supervises or controls medical practice in countless ways.").

216. 42 U.S.C. § 1395c (2012); see also Patricia Barry, Do You Qualify for Medicare?, AARP BULLETIN (Jan. 21, 2014), http://www.aarp.org/health/medicare-insurance/info-042011/medicare-eligibility.html [http://perma.cc/V8WY-93YV] (explaining who qualifies for Medicare). Medicare also covers certain individuals who are under 65 years of age, such as those with end-stage renal disease. See id. 
"reasonable and necessary for the diagnosis or treatment of illness or injury or to improve the functioning of a malformed body member."217 The Centers for Medicare and Medicaid Services (CMS) - the federal agency that administers Medicare-determines what items and services qualify as "reasonable and necessary," and how much to pay for them. ${ }^{218}$

Medical decisions, in turn, are affected by which products and services are covered, and the amount that Medicare pays for them. For example, one study found that a provision in the Medicare Prescription Drug, Improvement, and Modernization Act of 2003 (MMA) ${ }^{219}$ that changed how physician reimbursements for outpatient chemotherapy drugs were calculated, affected which chemotherapy drugs physicians prescribed for their patients with metastatic cancer. ${ }^{220}$ Physicians generally bill Medicare directly for drugs that the physician purchases and administers to the patient, like chemotherapy drugs. ${ }^{221}$ Before the MMA was enacted, physicians were reimbursed for such drugs at ninety-five percent of the Average Wholesale Price of the drug, ${ }^{222}$ which created a financial incentive to administer drugs for which the difference between the physician's cost and ninety-five percent of Average Wholesale Price was greatest. ${ }^{223}$ After the MMA eliminated this incentive, oncologists selected different

217. 42 U.S.C. $\$ 1395 y(a)$ (2012).

218. See 42 U.S.C. $\S \S 1395$ g, 1395w-4 (2012); MediCARE Payment Advisory COMM'N, REPORT TO THE CONGRESS: MEDICARE PAYMENT POLICY 245 (Mar. 2003), available at http://www.medpac.gov/documents/reports/Mar03_Entire_report.pdf?sfvrsn=0 [http:// perma.cc/5M48-NPMK].

219. Pub. L. No. 108-173, 117 Stat. 2066 (2003).

220. Mireille Jacobson et al., Does Reimbursement Influence Chemotherapy Treatment for Cancer Patients?, 25 Health AfF. 437, 437 (2006).

221. See DeP't Of HeAlth \& Human SERVS., OfFice of InSPECtor Gen.: MedicAre REIMBURSEMENT OF PRESCRIPTION DRUGS 1 (Jan. 2001), available at https://oig.hhs.gov/ oei/reports/oei-03-00-00310.pdf [https://perma.cc/WWZ6-JA4F]. Physicians also receive a separate fee for administering the drug, which is intended to compensate their time and effort, and the expenses of operating a medical practice. See U.S. GEN. ACCOUNTING Office, Report to Congressional Committees, Medicare: Payments for Covered OutPATIENT DRugs EXcEed PROVIDERS' Cost 14 (Sept. 2001) [hereinafter GAO, MEDICARE REPORT], available at http://www.gao.gov/new.items/d011118.pdf [http://perma.cc/89DXSQQT].

222. See Jacobson et al., supra note 220, at 437. The Average Wholesale Price is a term that CMS has defined by regulation. See 42 C.F.R. $\S 405.517$ (2014).

223. See GAO, MEDICARE Report, supra note 221, at 4. Although physicians could have elected to bill Medicare at rates below ninety-five percent of the Average Wholesale Price, very few did. See id. 
chemotherapy drugs for their patients with metastatic cancer. ${ }^{224}$ In other words, the study found that the amount of reimbursement did not affect whether oncologists treated their patients with chemotherapy, but did affect which chemotherapy drugs oncologists prescribed their patients. ${ }^{225}$ Similarly, a study of a 1991 change in Medicare's reimbursement policy for recombinant human erythropoietin treatment for dialysis patients demonstrated that the change in policy affected patients' treatment. ${ }^{226}$ Specifically, after the policy change tied reimbursement more closely to the amount of erythropoietin that was administered to a patient, the mean dose per treatment increased. ${ }^{227}$ These studies demonstrate that, by deciding what products and services are covered and their reimbursement amounts, Congress and CMS can influence medical practice. Beyond influencing medical practice through payment structures, Congress also has used Medicare to more directly regulate medical practice by, for example, restricting to whom a healthcare provider may refer Medicare patients. ${ }^{228}$

Thus, it is unsurprising that, similar to the other examples in this section, there is concern that Medicare could affect medical practice. This is most clearly demonstrated by language in the Medicare statute that explicitly prohibits federal interference with medical practice. ${ }^{229}$ Yet, as the studies described above make clear, this language has not had the desired effect of completely preventing Medicare's interference with medical practice, and courts have generally rejected arguments that Medicare policies interfere with medical practice in violation of this provision. ${ }^{230}$ Additionally, because private insurers often follow Medicare's lead, the effect of the federal government's decisions likely reach beyond Medicare patients. ${ }^{231}$

224. See Jacobson et al., supra note 220, at 442.

225. See id.

226. See Neil. R. Powe et al., Medicare Payment Policy and Recombinant Erythropoietin Prescribing for Dialysis Patients, 22 AM. J. KIDNEY DisEASE 557, 557 (1993).

227. See id.

228. See 42 U.S.C. $\S 1395 n n(2012)$.

229. See 42 U.S.C. $\$ 1395$ (2012).

230. See, e.g., Coll. of Am. Pathologists v. Heckler, 734 F.2d 859, 867-68 (D.C. Cir. 1984); Home Health Care, Inc. v. Heckler, 717 F.2d 587, 589-91 (D.C. Cir. 1983); Szekely v. Fla. Med. Ass'n, 517 F.2d 345, 350 (5th Cir. 1975); Rasulis v. Weinberger, 502 F.2d 1006, 1010 (7th Cir. 1974); Portland Adventist Med. Ctr. v. Heckler, 561 F. Supp. 1092, 1098 (D.D.C. 1983); Am. Med. Ass'n v. Mathews, 429 F. Supp. 1179, 1189-91, 1201-03 (N.D. Ill. 1977); see also Ass'n of Am. Physicians \& Surgeons v. Weinberger, 395 F. Supp. 125, 134 (N.D. Ill. 1975) (finding a law that established professional standards physicians must meet to be compensated under Medicare or Medicaid did not interfere with medical practice), aff'd mem., 423 U.S. 975 (1975).

231. See, e.g., Jeffrey P. Clemens \& Joshua D. Gottlieb, Bargaining in the Shadow of a Giant: Medicare's Influence on Private Payment Systems (Nat'l Bureau of Econ. 


\section{B. Far-Reaching Federal Powers}

The above examples of direct and indirect federal regulation contradict the maxim that states are the sole, or primary, regulators of medical practice. However, each of these examples was well within Congress's constitutional powers. In fact, the Constitution authorizes the federal government to further extend its reach into medical practice. ${ }^{232}$ Congress could exercise its commerce, spending, and taxing powers, among others, to govern most - if not all-medical practice.

\section{Commerce Powers}

The Supreme Court has explained that the reach of the Commerce Clause is broad. ${ }^{233}$ It authorizes Congress to regulate "the channels of interstate commerce, persons or things in interstate commerce, and those activities that substantially affect interstate commerce."234 It is this third category - activities that substantially affect interstate commerce - that has enabled the federal government to regulate a wide range of seemingly local activities, including intrastate sale of milk, ${ }^{235}$ growing wheat for one's own use, ${ }^{236}$ loan sharking, ${ }^{237}$ and growing marijuana for intrastate use. ${ }^{238}$

Given this reach, it is difficult to imagine a circumstance in which medical practice does not substantially affect interstate commerce. ${ }^{239}$ First, medical practice is clearly a commercial activity that is part of an

Research, Working Paper No. w19503, 2013), available at http://ssrn.com/abstract=233 6368 [http://perma.cc/X72J-YTA2].

232. Cf. Pharm. Mfrs. Ass'n v. Food \& Drug Admin., 484 F. Supp. 1179, 1187 (D. Del. 1980) aff'd, 634 F.2d 106 (3d Cir. 1980) ("It is undisputed that the practice of medicine is subject to the exercise of state police power.... But that assumption does not imply an absence of federal jurisdiction . . . where the federal regulation constitutes a reasonable exercise of a power vested in Congress under the Constitution.").

233. See, e.g., Nat'l Fed'n of Indep. Bus. v. Sebelius, 132 S. Ct. 2566, 2578-79 (2012)

234. Id. at 2578 (internal citations and quotations omitted).

235. See United States v. Wrightwood Dairy Co., 315 U.S. 110, 121 (1942).

236. See Wickard v. Filburn, 317 U.S. 111, 127-28 (1942).

237. See Perez v. United States, 402 U.S. 146, 154 (1971).

238. See Gonzales v. Raich, 545 U.S. 1, 32-33 (2005).

239. Cf. Noah, supra note 25 , at 169 (arguing that modern medical practice is subject to the federal government's commerce powers); King, supra note 24, at 331 (explaining that all eight circuit courts that have considered the issue have concluded that reproductive clinics engage in interstate commerce). 
"economic enterprise."240 In 2009, the most recent year for which the U.S. Census Bureau has published data, the United States spent $\$ 1.7609$ trillion on medical services, ${ }^{241}$ which constituted approximately $12 \%$ of the U.S. gross domestic product (GDP) that year. ${ }^{242}$ Second, modern medical practice involves "concrete ties" to interstate commerce. ${ }^{243}$ Practitioners are often part of large insurance networks or hospital chains that operate in multiple states. ${ }^{244}$ Patients may travel across state lines for treatment, particularly for innovative or specialist care, ${ }^{245}$ and practitioners may advertise to attract out-of-state patients. ${ }^{246}$ Additionally, many health problems that are affected by medical practice - such as prescription drug abuse, which costs the United States an estimated $\$ 72$ billion a year ${ }^{247}$-impact the national economy. Based upon these facts, Congress would be justified in finding that many, if not all, aspects of medical practice substantially affect interstate commerce and therefore, in enacting a federal law regulating it. ${ }^{248}$

Congress has done just that. Relying on its commerce powers, Congress has enacted laws that directly and indirectly regulate medical practice. ${ }^{249}$ Moreover, courts have recognized these laws as valid exercises of the government's commerce powers. For example, Justice Kennedy's majority opinion in Gonzales v. Carhart, which upheld the Partial-Birth Abortion

240. United States v. Lopez, 514 U.S. 549, 561 (1995).

241. U.S. Census Bureau, Statistical Abstract of the United States: 2012 101 tbl.134 (2012), http://www.census.gov/compendia/statab/2012/tables/12s0134.pdf [http://perma.cc/9J34-QY62].

242. This percentage was calculated based on the World Bank's report that U.S. GDP was \$14.4179 trillion in 2009. World Development Indicators, WorLD DATABANK, http://databank.worldbank.org/data/views/reports/tableview.aspx?isshared=true (last visited Feb. 11, 2015). All health care spending amounted to approximately $18 \%$ of the U.S. GDP. Health Expenditure, Total (\% of GDP), WORLD DATABANK, http://data.world bank.org/indicator/SH.XPD.TOTL.ZS [http://perma.cc/H6RS-7TDY] (last visited Feb. 11,2015 ).

243. Lopez, 514 U.S. at 567.

244. See Noah, supra note 25 , at 169.

245. Id. at 170 .

246. For example, the website for one of the largest U.S. fertility clinics, located in Maryland, specifically welcomes patients from other states. World Class IVF and Egg Donor Treatment For International and U.S. Patients, SHADY Grove FerTILITY, http://www.shady grovefertility.com/out_of_area [http://perma.cc/G49T-2XVA] (last visited Feb. 11, 2015).

247. U.S. Dep't of Health \& Human Servs., Addressing Prescription Drug ABuse In the United StATES: CuRRENT ACtivities AND Future OpPortunities 5 (2013) [hereinafter HHS REPORT ON PRESCRIPTION DRUG ABUSE], available at http://www.cdc. gov/HomeandRecreationalSafety/pdf/HHS_Prescription_Drug_Abuse_Report_09.2013.pdf [http://perma.cc/2CRZ-97C5].

248. Cf. Lopez, 514 U.S. at 562 (noting that "under the Commerce Clause [the Court] of course consider[s] legislative findings").

249. See section III.1, supra. 
Ban Act, noted that Congress enacted the law under its commerce powers. ${ }^{250}$ Similarly, the D.C. Circuit upheld Federal Trade Commission regulations governing the profession of optometry as within the federal government's commerce powers. ${ }^{251}$ Congress could go further by, for instance, restricting off-label use of additional drugs.

It is also worth noting that the limits on Congress's commerce powers articulated in National Federation of Independent Businesses v. Sebelius do not apply to the argument that medical practice substantially affects interstate commerce. Chief Justice Roberts's opinion in National Federation of Independent Businesses explained that the individual mandate in the PPACA was not a permissible exercise of Congress's commerce powers because it compelled otherwise inactive individuals to become active in commerce. ${ }^{252}$ But in the medical practice context, practitioners are already active in commerce - in other words, there is "existing commercial activity" to regulate. ${ }^{253}$ In sum, even if medical practice was once a local activity outside the scope of Congress's commerce powers, modern medical practice substantially affects interstate commerce and thus, is within the federal government's reach. ${ }^{254}$

250. Gonzales v. Carhart, 550 U.S. 124, 166 (2007). The law, by its own terms, applies only to those physicians who are "in or affect [] interstate or foreign commerce." Partial-Birth Abortion Ban Act, 18 U.S.C. $\S 1531$ (a) (2003). Justice Thomas, in his concurring opinion joined by Justice Scalia, took care to note that "whether the PartialBirth Abortion Ban Act . . . constitutes a permissible exercise of Congress' power under the Commerce Clause is not before the Court." Carhart, 550 U.S. at 169 (Thomas, J., concurring). This may suggest some skepticism, by at least Justices Thomas and Scalia, that the commerce powers reach abortion procedures.

251. See Am. Optometric Ass'n v. FTC, 626 F.2d 896, 916 (D.C. Cir. 1980); see also LensCrafters, Inc. v. Wadley, 248 F. Supp. 2d 705, 729 (M.D. Tenn. 2003) ("[The D.C. Circuit] has upheld federal regulations requiring optometrists to provide their patients with copies of their prescriptions . . . thereby implicitly rejecting the argument that the profession of optometry is exempt from federal commercial regulation.").

252. See Nat'l Fed'n of Indep. Bus. v. Sebelius, 132 S. Ct. 2566, 2587 (2012).

253. Id. at 2587.

254. Cf. New York v. United States, 505 U.S. 144, 158 (1992) (“As interstate commerce has become ubiquitous, activities once considered purely local have come to have effects on the national economy, and have accordingly come within the scope of Congress' commerce power."). 


\section{Spending Powers}

The spending clause "provides Congress broad discretion to ... spend for the 'general Welfare,' including by funding particular . . . private programs or activities," and "[t]hat power includes the authority to impose limits on the use of such funds to ensure they are used in the manner Congress intends." 255 For example, in rejecting a First Amendment challenge to regulations that prohibited practitioners who received federal familyplanning funds from discussing abortion with their patients, the Supreme Court opined:

The Government can, without violating the Constitution, selectively fund a program to encourage certain activities it believes to be in the public interest, without at the same time funding an alternative program which seeks to deal with the problem in another way. In so doing, the Government . . . has merely chosen to fund one activity to the exclusion of the other. 256

Because the federal government pays almost half of all health care expenses in the United States, ${ }^{257}$ Congress's spending powers provide an avenue for regulating a significant amount of medical practice: selectively funding medical services and placing conditions on those who receive payments. Indeed, the federal government already exercises its spending powers in this way. Federally-funded health care systems, such as the Veterans Health Administration ${ }^{258}$ or the Indian Health Service, ${ }^{259}$ are clearly controlled by the federal government. Additionally, as discussed above, Medicare reimburses only those items and services that CMS determines

255. Agency for Int'l Dev. v. Alliance for Open Soc'y Int'l, Inc., 133 S. Ct. 2321, 2327-28 (2013) (citing Rust v. Sullivan, 500 U.S. 173, 195 n.4 (1991); see also U.S. Const. art. I, $\S 8$, cl. 1 ("Congress shall have Power To lay and collect Taxes, Duties, Imposts and Excises, to pay the Debts and provide for the common Defence and general Welfare of the United States ...."). Although Congress's spending and taxing powers come from the same clause of the Constitution, this Article addresses them separately for clarity.

256. Rust, 500 U.S. at 193. The majority opinion also rejected the argument that the regulations violated a woman's Fifth Amendment right to terminate her pregnancy, reasoning that "Congress' refusal to fund abortion counseling and advocacy leaves a pregnant woman with the same choices as if the Government had chosen not to fund family-planning services at all." Id. at 202.

257. Org. For Econ. Dev., OECD Health Statistics 2014: How Does the United STATES COMPARE? 1, available at http://www.oecd.org/unitedstates/Briefing-NoteUNITED-STATES-2014.pdf [http://perma.cc/DTX8-445V].

258. See Veterans Health Administration, U.S. DePARtment of Veterans AfF., http://www.va.gov/health/ [http://perma.cc/FJ2U-CV35] (last visited Feb. 11, 2015). The Veteran's Health Administration is the largest health system in the United States, "providing care to more than 8.3 million veterans per year." Id.

259. See About HIS, U.S. Department OF Health \& Human SERVICES, Indian HEALTH SERVICE, http://www.ihs.gov/aboutihs/ [http://perma.cc/R9XU-QH83] (last visited Feb. 11, 2015). 
are "reasonable and necessary," 260 and the federal government places limits on health care practitioners who receive Medicare and Medicaid funds. For instance, a physician cannot refer Medicare and Medicaid patients to other health care providers in which that physician has a financial interest. ${ }^{261}$

Here, like the commerce context, the federal government could go further than it currently does. As an example, recent research suggests that when pediatricians present vaccination as an option, rather than a foregone conclusion, parents are more likely to decline recommended vaccinations for their children. ${ }^{262}$ Research also indicates that many pediatricians agree to parents' requests to spread out recommended vaccines for their children, despite concerns that spreading out vaccines puts the children at risk for disease and is more painful for the children. ${ }^{263}$ Accordingly, Congress might choose to fund programs to encourage childhood vaccination, and prohibit participating practitioners from spreading out vaccinations, or providing information about exemptions from state laws mandating vaccination. ${ }^{264}$

To the extent the federal government offers funding to the states for health-related programs, it might also reach medical practice by "condition[ing] those offers on compliance with specified conditions."265 In the wake of National Federation of Independent Businesses, in which seven of the Court's justices found that placing new conditions on the existing level of federal funding for states' Medicaid programs was unconstitutionally coercive, ${ }^{266}$ scholars have suggested that the era in which conditions on states' receipt of federal funds were essentially unchecked has ended. ${ }^{267}$ Yet, even with stronger limits on the federal government's ability to place conditions on state funds, the federal government may be able reach certain aspects of medical practice. For

260. See 42 U.S.C. $§ 1395 \mathrm{~g}(2012)$.

261. See 42 U.S.C. $\S 1395 \mathrm{nn}(2012)$.

262. See Douglas J. Opel et al., The Architecture of Provider-Parent Vaccine Discussions at Health Supervision Visits, 132 Pediatrics 1037, 1037 (2013).

263. See Allison Kempe et al., Physician Response to Parental Requests to Spread Out the Recommended Vaccine Schedule, 135 PEDIATRICs 666, 666 (2015).

264. For an overview of state laws regarding vaccinations, see Immunization Managers, Requirements and Laws, CENTERS FOR DisEASE CONTROL AND PREVENTION, http://www.cdc. gov/vaccines/imz-managers/laws/ [http://perma.cc/MFW8-ABCR] (last updated Feb. 3, 2015).

265. Nat'l Fed'n of Indep. Bus. v. Sebelius, 132 S. Ct. 2566, 2579 (2012).

266. See id. at 2587.

267. See, e.g., Wendy E. Parmet \& Peter D. Jacobson, The Courts and Public Health: Caught in a Pincer Movement, 104 Am. J. PuB. HeAlth 392, 394 (2014); Lynn A. Baker, The Spending Power After NFIB v. Sebelius, 37 HARV. J.L. \& PUB. POL'Y 71, 72-73 (2014). 
example, to address prescription drug abuse, the federal government might condition the receipt of new federal funds for Medicaid on states establishing a database to track prescriptions for drugs of abuse, and requiring practitioners to report prescriptions to the database. ${ }^{268}$

\section{Taxing Powers}

Congress's taxing powers provide another avenue for influencing medical practice. The federal government's taxing powers, like its commerce and spending powers, are quite broad. The taxing clause "gives the Federal Government considerable influence even in areas where it cannot directly regulate. The Federal Government may enact a tax on an activity that it cannot authorize, forbid, or otherwise control."269 The federal government may impose taxes to "influence conduct," as long as those taxes do not become so punitive as to be penalties. ${ }^{270}$ Chief Justice John Roberts's opinion in National Federation of Independent Businesses v. Sebelius - upholding the PPACA's individual mandate as a permissible exercise of Congress's taxing powers - made clear that "the breadth of Congress's power to tax is greater than its power to regulate commerce." 271

Congress has used its taxing powers in the past to control medical practice. As an example, the Marihuana Tax Act of 1937 imposed a yearly tax on medical practitioners who compounded, dispensed, prescribed, or administered marijuana, ${ }^{272}$ and was opposed by the AMA based on concerns that the "prohibitive tax" would prevent physicians and pharmacists from prescribing and dispensing the drug. ${ }^{273}$ Although the Controlled Substances Act of 1970 repealed this law, ${ }^{274}$ there are other ways in which the federal government might aim to influence various aspects of medical practice through its taxing authority. The federal government might, for instance, impose a tax on physicians with high prescription rates for

268. As of 2011, thirty-seven states had prescription drug monitoring programs along these lines. See State Prescription Drug Monitoring Programs, U.S. DEP'T OF JusT., OFF. OF DIVERSION CONTROL, http://www.deadiversion.usdoj.gov/faq/rx_monitor.htm\#4 [http://perma.cc/Q3ZY-9M43] (last updated Oct. 2011).

269. Sebelius, 132 S. Ct. at 2579.

270. Id. at 2599 .

271. Id. at 2600

272. Marihuana Tax Act of 1937, 50 Stat. 551, 551-52 (1937).

273. Taxation of Marihuana: Hearing Before H. Comm. on Ways and Means, 75 th Cong. 91 (1937) (statement of Dr. William C. Woodward, Legislative Counsel, American Medical Association).

274. The Comprehensive Drug Abuse Prevention and Control Act of 1970, Pub. L. No. 91-513, §§ 100-709, 84 Stat. 1236, 1281 (1970). The Marihuana Tax Act was repealed after the Supreme Court held the law unconstitutional to the extent compliance with it amounted to self-incrimination under state narcotic laws. See Leary v. United States, 395 U.S. 6, 28 1969). 
controlled substances, to address prescription drug abuse by discouraging the over-prescription of such drugs. ${ }^{275}$

\section{Other Sources of Power}

In addition to exercising its commerce, spending, and taxing powers, there are various other ways, somewhat different than the previous examples, through which the federal government could, and does, directly and indirectly influence certain realms of medical practice. As an example of direct regulation, the federal government heavily regulates medical practice in the military, directly restricting military practitioners' autonomy when necessary to further the goal of maintaining an effective fighting force. ${ }^{276}$ If a practitioner were to disobey orders to provide particular medical care, the practitioner could be punished, and that punishment likely would be upheld as a valid exercise of the federal government's military powers. ${ }^{277}$

While the previous example demonstrates direct regulation of medical practice, the federal government's grants of certain patents, pursuant to the Patent and Copyright Clause, ${ }^{278}$ represents indirect regulation of medical practice. Patents can affect medical practice even though federal law explicitly eliminates patent infringement remedies against medical practitioners

275. In fact, physicians who register with the DEA to prescribe controlled substances already pay fees. See Registration Categories and Fees, U.S. DeP'T OF Just., OfF. OF DIVERSION CONTROL, http://www.deadiversion.usdoj.gov/drugreg/categories.htm [http://perma. cc/BWE4-J532]. Moreover, tracking physician-prescribing patterns would be feasible because it is something that some drug companies already do. See Scott Glover \& Lisa Girion, OxyContin Maker Closely Guards Its List of Suspect Doctors, L.A. TIMES, Aug. 11, 2013, http://articles.latimes.com/2013/aug/11/local/la-me-rx-purdue-20130811 [http://perma. cc/658G-G2WM].

276. See Victor W. Sidel \& Barry S. Levy, Physician-Soldier: A Moral Dilemma?, in Military Medical Ethics 293, 296 (Thomas E. Beam \& Linette R. Sparacino eds., 2003); Efthimios Parasidis, Justice and Beneficence in Military Medicine and Research, 73 Oнiо Sт. L.J. 723, 792 (2012); Robert N. Strassfeld, The Vietnam War on Trial: The Court-Martial of Dr. Howard B. Levy, 1994 Wis. L. REV. 839, 849 (1994).

277. Cf. U.S. CONST. art. I, § 8, cl. 16 (authorizing the federal government " $[\mathrm{t}] \mathrm{o}$ provide for organizing, arming, and disciplining, the Militia, and for governing such Part of them as may be employed in the Service of the United States"); Parker v. Levy, 417 U.S. 733, 761 (1974) (upholding the court-martial of a military doctor who, among other things, refused to provide medical training to soldiers); Gordon D. Henderson, CourtsMartial and the Constitution: The Original Understanding, 71 HARV. L. REV. 293, 299300 (1957) (explaining that courts-martial predated the Constitution, but at least some framers believed the militia clause authorized the continuation of courts-martial).

278. U.S. CONST. art. I, $\S 8, \mathrm{cl} .8$. 
who infringe certain medical procedure patents. ${ }^{279}$ For example, to the extent patents on medical products block the marketing of competitor products, ${ }^{280}$ patents granted by the U.S. Patent and Trademark Office, much like the FDA's gatekeeping, can determine the universe of treatments that a medical practitioner may provide. As another example, patents on genetic material have been used to prevent practitioners from providing genetic testing services to their patients. ${ }^{281}$ Although a 2013 Supreme Court decision invalidated one genetic testing company's patents on "isolated genes," it upheld the company's patents on another type of genetic material — known as cDNA — and, until recently, the company continued to pursue patent infringement claims against those offering genetic tests arguably covered by these its patents. ${ }^{282}$ Likewise, insofar as medical process patents cover patent-eligible subject matter, they have been used to restrict the treatment options that practitioners can provide. ${ }^{283}$ Thus, Congress's commerce, spending, and taxing powers are not the only means by which it can govern medical practice.

\section{What to Make of the Existing Federal Oversight}

Because the Constitution authorizes Congress to extensively regulate medical practice, there is nothing unlawful about the examples of federal oversight described in section III.A. Nevertheless, given the historical resistance to various guises of federal oversight of medicine, such as

279. See 35 U.S.C. § 287(c); Katherine J. Strandburg, Legal But Unacceptable: Pallin v. Singer and Physician Patenting Norms, in InTELlectUAL ProPerTy AT THE Edge: The Contested Contours of IP 321, 321 (Rochelle Cooper Dreyfus \& Jane C. Ginsburg, eds. 2014).

280. See, e.g., Larry Husten, Medtronic to Pay Over $\$ 1$ Billion to Settle Patent Litigation with Edwards Lifesciences, FoRBES.COM (May 20, 2014), http://www.forbes. $\mathrm{com} /$ sites/larryhusten/2014/05/20/medtronic-to-pay-over-1 billion-to-settle-patent-litigationwith-edwards-lifesciences/ [http://perma.cc/73MJ-WRGT] (describing a now settled patent dispute between two medical device companies, which would have limited the availability of certain medical devices in the United States).

281. See, e.g., Ass'n for Molecular Pathology v. Myriad Genetics, Inc., 133 S. Ct. 2107, $2114(2013)$

282. See id. at 2119, 2120; Jacob S. Sherkow \& Christopher Scott, Myriad Stands Alone, 32 Nature Biotechnology 620, 620 (2014); Utah Court Dismisses Two More BRCA Testing Patent Lawsuits Against Labcorp, Ambry, GenomeWeB (Jan. 27, 2015), available at https://www.genomeweb.com/business-news/utah-court-dismisses-two-morebrca-testing-patent-lawsuits-against-labcorp-ambry [https://perma.cc/3BVE-CNNM]; see also In re BRCA1- \& BRCA2-Based Hereditary Cancer Test Patent Litig., 774 F.3d 755 (Fed. Cir. 2014) (holding that certain inventions that closely implicate the information contained in genomic DNA are not patentable).

283. See Mayo Collaborative Servs. v. Prometheus Labs., Inc., 132 S. Ct. 1289, 1302 (2012); Aaron S. Kesselheim \& Michelle M. Mello, Medical-Process Patents-Monopolizing the Delivery of Health Care, 355 N. ENG. J. MED. 2036, 2037-38 (2006). 
health care reform, and the traditional reliance on states to regulate medical practice, ${ }^{284}$ these examples of federal regulation of medical practice raise questions about why federal oversight was accepted - or established - in these instances, and whether the current approach to federal regulation is sensible.

Perhaps the most practical answer to the first question-why these examples of federal oversight were accepted - is that, in many of the instances in which the impact on medical practice was recognized, it was also argued that that the law at issue did not, in fact, regulate medical practice. In other words, it was argued that notwithstanding the ways that these federal programs influence medicine, these federal programs are consistent with the conventional view that states regulate medical practice. For instance, in hearings before a Senate Subcommittee prior to the CSA's enactment, the director of the Bureau of Narcotics and Dangerous Drugs within the Department of Justice assured lawmakers that the CSA was "in no way intended to authorize the Attorney General to regulate the practice of medicine, nor will it have this effect." 285 Likewise, in hearings about the 1962 amendments to the FDCA that authorized the FDA to review the effectiveness of drugs, the AMA spokesperson's concern that this new authority would interfere with medical practice was characterized by others speaking at the hearing as "specious." 286 The legislative history for FDAAA suggests that Congress did not discuss the impact of REMS on medical practice when enacting the law. But when the FDA implemented regulations in 1992 to create "RiskMAPs"-risk mitigation programs that were similar to $\mathrm{REMS}^{287}$-it responded to comments asserting that RiskMAPs "interfere with the practice[] of medicine" by characterizing the regulations as "permit[ing], in exceptional cases, approval of drugs with restrictions so that the drugs may be available for prescribing and dispensing," rather than "interfering with physician or pharmacy practice."288 And, as noted above, the Medicare statute includes a provision explicitly disavowing any intent to regulate medical practice. ${ }^{289}$

284. See supra section II.

285. 1970 CSA Senate Hearing, supra note 171.

286. Harris, The Real Voice-II, supra note 196, at 146.

287. See, e.g., DRAFT REMS GUIDANCE, supra note 201, at 3-5.

288. New Drug, Antibiotic, and Biological Drug Product Regulations; Accelerated Approval, 57 Fed. Reg. 58942, 58951-52 (Dec. 11, 1992) (to be codified at 21 C.F.R. pts. 314 \& 601), available at http://www.gpo.gov/fdsys/pkg/FR-2003-06-11/pdf/03-14621.pdf [http://perma.cc/SZF7-E28P].

289. See 42 U.S.C. $§ 1395$ (2014). 
Denying that federal programs control medical practice may be politically useful because of the history of state regulation and of opposition to federal oversight. It gives Congress and administrative agencies cover from opposition grounded in concern about federal, rather than state, regulation, and allows them to make an argument that the particular federal program at issue is consistent with the traditional division of labor between the states and the federal government. But it also requires lawmakers and administrative agencies to obfuscate the impact that these federal laws have on medical practice. Transparency in governance is considered to be "among the pantheon of great political virtues," 290 because it facilitates democratic accountability and the better implementation of laws. ${ }^{291}$ Obfuscating the federal government's role in overseeing medicine is, thus, undesirable, particularly at a time when the White House has emphasized the value transparency in government. ${ }^{292}$ Moreover, the need for rhetoric denying federal influence over medicine in areas that it exists suggests that the current approach to federal oversight is not the most sensible one.

In addition to the political explanation for why the federal government was able to implement measures to influence medical practice in these examples, another reason that the above examples of federal oversight were established may be that Congress focused on issues that were-or were perceived to be-of national concern. For example, Congress prohibited off-label use of HGH after U.S., ${ }^{293}$ and international, ${ }^{294}$ scandals about athletes using performance-enhancing drugs sparked widespread concern in the United States. ${ }^{295}$ At the time Congress enacted the PartialBirth Abortion Ban Act, more than half of states had already enacted laws

290. Mark Fenster, The Opacity of Transparency, 91 IowA L. REV. 885, 888 (2006). While scholars have critiqued the concept of transparency and noted certain drawbacks associated with the implementation of open government laws in the United States, such critiques would not apply to this kind of obfuscation of the federal government's role.

291. See, e.g., Robert G. Vaughn, Transparency in the Administration of Laws: The Relationship Between Differing Justifications for Transparency and Differing Views of Administrative Law, 26 AM. U. INT'L L. REV. 969, 970 (2011) (describing the justifications for transparency).

292. See Transparency and Open Government: Memorandum for the Heads of Executive Departments and Agencies, 74 Fed. Reg. 4685 (Jan. 26, 2009).

293. See supra notes $182-83$ and accompanying text.

294. See Tim Keeney, Ben Johnson: Is 1988 Olympics Scandal Biggest of All Time?, BLEACHER REPORT (Oct. 9, 2012), http://bleacherreport.com/articles/1365158-benjohnson-is-1988-olympics-scandal-biggest-of-all-time [http://perma.cc/52C3-DETV.

295. See, e.g., Abuse of Steroids in Amateur and Professional Athletics: Hearing Before the Subcomm. on Crime of the H. Comm. on the Judiciary, 101st Cong. (1990). 
attempting to ban partial-birth abortions, ${ }^{296}$ suggesting this procedure may have been of national concern. Further, the enactment of the 1962 law authorizing the FDA to review drugs' efficacy followed a well-publicized public health scare, when the FDA refused to approve a drug called thalidomide that was later linked to severe birth defects, highlighting drugs' potential for affecting the nation's public health. ${ }^{297}$

Although these federal efforts were aimed at problems of national interest, the overall approach to federal oversight of medicine is haphazard. It may be the case that the federal government only intervenes when issues of national concern are at stake, but the federal government does not consistently intervene in such circumstances, which leads to inconsistent and problematic public health policy. The deadly 2012 outbreak of fungal meningitis that was linked to the state-regulated practice of drug compounding, and the enduring idea, even after the outbreak, that the federal government should not regulate compounding that constitutes medical practice ${ }^{298}$ illustrates that the federal government does not consistently step in to address medical practice problems of national significance, and that the conventional view on the appropriate role for the federal government can lead to questionable public health policy.

In sum, both political rhetoric denying that federal laws interfere with medical practice, and the national implications of the issues that federal laws have addressed, likely enabled the federal government to establish oversight of the areas of medical practice identified in the examples in this section. But this approach to federal oversight of medicine is opaque and lacks a coherent underlying principle, which leads to inconsistent and problematic policy.

\section{WHEN FEDERAL REGULATION IS WARRANTED}

Given that federal regulation of medicine already exists and is generally lawful, but the scope of that federal oversight is currently inconsistently and ineffectively defined, the question becomes one long debated in many areas of U.S. policy: under what circumstances should the federal

296. See, e.g., Nancy Kubasek \& Daniel Tagliarina, Failed Lessons of History: The Predictable Shortcomings of the Partial-Birth Abortion Ban Act, 6 U. MD. L.J. RACE, RELIGION, GENDER \& ClASS 159, 163 (2006).

297. See, e.g., DANiEl CARPENTER, Reputation AND Power: Organizational IMAGE AND PHARMACEUTICAL REgUlATION AT THE FDA 229-30, 238-40 (2010).

298. See supra notes $1-6$ and $11-15$ and accompanying text. 
government exert its authority? ${ }^{299}$ This Article proposes that federal regulation of medical practice is warranted when medical practice causes or contributes to a national public health problem that states cannot address.

\section{A. The Case for Federal Regulation}

Scholars and courts have attributed numerous merits to state-based regulatory schemes, ${ }^{300}$ and scholars have identified a "general presumption in favor of decentralization." 301 One common argument is that "state governments limit the likelihood of federal tyranny." 302 Another is that, similar to competition in private markets, competition between states for "resident-taxpayers" may encourage states to provide optimal levels of regulation. ${ }^{303}$ State regulation also may allow greater political participation. ${ }^{304}$ David L. Shapiro explained, "to the extent the electorate is small, and elected representatives are thus more immediately accountable to individuals and their concerns, government is brought closer to the people, and democratic ideals are more fully realized." ${ }^{305}$ Decentralized regulation may enable experimentation and innovation, with the states functioning as "laboratories for new ideas," 306 and accommodate cultural and local diversity that would be threatened by national uniformity. ${ }^{307}$ In areas that have traditionally

299. Cf. Brendan S. Maher, The Benefits of Opt-in Federalism, 52 B.C. L. REV. 1733, 1734 (2011) ("The constitutional dispute [about the PPACA] is part of a larger argument that is perhaps America's oldest: what is the proper role of the federal government?").

300. See, e.g., Gregory v. Ashcroft, 501 U.S. 452, 458 (1991); Abigail R. Moncrieff, Federalization Snowballs: The Need for National Action in Medical Malpractice Reform, 109 COLUM. L. REV. 844, 879 (2009).

301. Jonathan H. Adler, Cooperation, Commandeering, or Crowding Out?: Federal Intervention and State Choices in Health Care Policy, 20 KAN. J.L. \& PUB. POL'Y, 199, 205 (2011); see also Richard L. Revesz, The Race to the Bottom and Federal Environmental Regulation: A Response to Critics, 82 MINN. L. REV. 535, 536 (1997) ("My starting point is a rebuttable presumption in favor of decentralization.").

302. Erwin Chemerinsky, The Values of Federalism, 47 Fla. L. REV. 499, 526 (1995); see also Michael W. McConnell, Federalism: Evaluating the Founders' Design, 54 U. CHI. L. REV. 1484, 1500 (1987) ("The most important reason offered by the defenders of state sovereignty was that state and local governments are better protectors of liberty.")

303. See Gregory, 501 U.S. at 458; Moncrieff, supra note 300, at 869; Charles M. Tiebout, A Pure Theory of Local Expenditures, 64 J. PoL. ECON. 416, 418-20 (1956)

304. See Gregory, 501 U.S. at 458; Chemerinsky, supra note 302, at 525; Barry Friedman, Valuing Federalism, 82 MinN. L. REV. 317, 389 (1997); Moncrieff, supra note 300 , at $879-81$.

305. DAVID L. Shapiro, Federalism: A Dialogue 91-92 (1995).

306. Chemerinsky, supra note 302, at 525; McConnell, supra note 302, at 1499; see also Gregory, 501 U.S. at 458 ("[Decentralization] allows for more innovation and experimentation in government ....").

307. See Gregory, 501 U.S. at 458; Friedman, supra note 304, at 401-02; McConnell, supra note 302 , at 1493 . 
been regulated by states, continuing state regulation may retain the expertise of the institutions that are most experienced, and provide stakeholders predictability. ${ }^{308}$ Finally, there may be less partisan gridlock at the state level than there currently is at the federal level, which may enable state lawmakers to more quickly implement new laws and policies than federal lawmakers can.

But scholars have also identified several advantages of federal regulation, including addressing interstate issues that create externalities, providing uniformity or coordination, preventing a "race to the bottom" among the states that threatens public welfare, and providing greater resources or expertise than the states possess. ${ }^{309}$ The presumption in favor of decentralization, thus, "can be overcome . . . by demonstrating the potential benefits of federal intervention in a specific instance." 310 A federal scheme need not deliver all possible benefits to be justified-one strong merit may be sufficient to "tip" the scales in favor of federal regulation. ${ }^{311}$ And in the specific context of medical practice, there are several potential benefits of federal regulation.

Despite the continuing narrative that medical practice is an individualized and local endeavor, ${ }^{312}$ it can easily contribute to problems that cross state boundaries and require nationally coordinated or uniform solutions. ${ }^{313}$ The fall 2012 outbreak of fungal meningitis, caused by drugs compounded at a Massachusetts pharmacy that were shipped to patients in twenty-three states, provides a vivid example. ${ }^{314}$ As early as April 2011, Colorado recognized a problem with the pharmacy's compounded drugs and blocked sales of its products in the state. ${ }^{315}$ Even though Colorado notified Massachusetts and the FDA, other states failed to take action to prevent

308. See Moncrieff, supra note 300, at 879-81.

309. See, e.g., Robert Glicksman \& Richard E. Levy, A Collective Action Perspective on Ceiling Preemption by Federal Environmental Regulation: The Case of Global Climate Change, 102 Nw. U. L. Rev. 579, 594-600 (2008); Amy L. Stein, The Tipping Point of Federalism, 45 ConN. L. REV. 217, 227 (2012).

310. Adler, supra note 301, at 205. Scholars have questioned whether state-based regulatory schemes do, in fact, provide these benefits. See, e.g., Chemerinsky, supra note 302 , at 255 .

311. See Stein, supra note 309, at 227.

312. See supra notes $44-50$ and accompanying text.

313. Cf. King, supra note 24, at 329 (describing the collective-action problem of the states); McConnell, supra note 302, at 1500 ("Externalities present the principal countervailing consideration in favor of centralized government ....").

314. See, e.g., Outterson, DQSA, supra note 13, at 97.

315. See id. 
the pharmacy's compounded drugs from reaching patients within their borders - there was no coordinated response to the problem. ${ }^{316}$ Additionally, the 2012 outbreak was not an isolated event; it might have been anticipated by a well-coordinated national system. In 2013 researchers identified eleven other similar outbreaks, between 2000 and the 2012 outbreak, caused by sterile drugs compounded outside of hospital settings, eight of which involved patients receiving compounded drugs across state lines. ${ }^{317}$

Interstate problems, and the need for national coordination or uniformity, have prompted scholars and commentators to call for federal regulation of various aspects of medical practice. For instance, Michael S. Young and Rachel K. Alexander have argued that a federal medical licensing system should be adopted because state licensure burdens practitioners "who work in this . . . extremely mobile society, who travel interstate, who treat patients from other states, or who participate in such activities as telemedicine." ${ }^{318}$ Abigail Moncrieff has called for federalizing the medical malpractice system to correct for interstate externalities created by a decentralized system. ${ }^{319}$ Scholars have also proposed federalizing health systems that are currently decentralized, which would amount to increased indirect federal regulation of medical practice to solve interstate problems. Nicole Huberfeld, for example, has argued for federalizing Medicaid to "create a more coherent, consistent, and equal program." 320

There are compelling public health reasons, in addition to the need to address interstate problems, for federal schemes for medical practice. Regulatory efforts that require significant scientific expertise may be more efficiently and effectively carried out at the federal level. Jaime S. King, for example, proposed federally regulating the use of assisted reproductive technologies in part for this reason. ${ }^{321}$ It also may be desirable

316. See id.

317. See Catherine Staes et al., Description of Outbreaks of Health-Care Associated Infections Related to Compounding Pharmacies, 2000-12, 70 AM. J. HEALTH-SySTEM PHARMACY e29, e30-31 (2013).

318. Michael S. Young \& Rachel K. Alexander, Recognizing the Nature of American Medical Practice: An Argument for Adopting Federal Medical Licensure, 13 DePAUL J. Health CARe L. 145, 166-67 (2010); see also George Annas, Congress, Controlled Substances, and Physician-Assisted Suicide-Elephants in Mouseholes, 354 New Eng. J. MED. 1079-1084 (2006) (opining that state licensure of medical practitioners is a "relic"). Other scholars, however, have argued for improving coordination between the states rather than federalizing medical licensure. See, e.g., Kocher et al., supra note 131 ("We believe that ... states should adopt mutual recognition agreements in which they honor each other's physician licenses.").

319. See Moncrieff, supra note 300, at 847-48.

320. Huberfeld, supra note 53, at 473.

321. See King, supra note 24, at 329, 338; see also Heled, supra note 24, at 304-07 (making recommendations for the FDA regulation of the genetic aspects of donated reproductive tissue). 
to federally govern certain aspects of medical practice to ensure a minimum level of protection for the public health and patients' safety. ${ }^{322}$ Perhaps in recognition of this possibility, Rebecca Dresser and Joel Frader argued Congress and the FDA should take a "more affirmative" role in overseeing off-label uses of drugs to prevent harm. ${ }^{323}$ Lastly, the federal government has greater financial resources than the states do, which permits the federal government to make longer-term investments and establish broader regulatory schemes than the states can. ${ }^{324}$ National public health problems may require the financial resources of the federal government and the long-term commitment those resources enable. As technology and scientific understanding advance, it may become increasingly likely that solutions to public health problems will outstrip states' abilities and resources. Federal resources might be used to establish federal initiatives that directly regulate medical practice or, if direct federal control is not needed, might be given to the states, with conditions intended to influence medical practice.

In fact, in many cases, federal oversight of medical practice need not wholly supplant state regulation to gain the benefits of federal oversight. It is true that for certain problems a single, uniform policy will be necessary or useful, and, accordingly it may be desirable to establish federal oversight that preempts divergent state oversight in those circumstances. For example, permitting individual states to make independent approval decisions about medical products could undermine the FDA's ability to protect and promote the public health, and create uncertainty for industry stakeholders that invest in and develop new medical products. ${ }^{325}$ But in many cases, even when a national public health problem has emerged, a wholesale federal takeover of medical practice regulation may not be necessaryoverlapping authorities can be beneficial, and regulators can learn from

322. See, e.g., Revesz, supra note 301 , at 544; cf. Noah, supra note 25, at 154 (“'[T] he federal government should not feel shy about interfering with the practice of medicine ... to ensure patient safety.").

323. Dresser \& Frader, supra note 45, at 483. Philip M. Rosoff and Doriane Lambelet Coleman have also proposed heightened regulation of off-label prescribing, but remain agnostic as to whether such regulation should be federal. See Philip M. Rosoff \& Doriane Lambelet Coleman, The Case for Legal Regulation of Physicians' Off-Label Prescribing, 86 Notre DAME L. ReV. 649, 690-91 (2011).

324. See Sage \& Hyman, supra note 24 , at 823.

325. Cf. Zogenix, Inc. v. Patrick, No. 14-11689-RWZ, 2014 WL 1454696, at *2 (D. Mass. Apr. 15, 2014) (enjoining a Massachusetts banon a FDA-approved drug-which was framed as a medical practice law- because it was preempted by the FDCA). 
each other's' experiences. ${ }^{326}$ In sum, federally regulating medical practiceeither directly and indirectly - may offer comparative advantages over sole state regulation for interstate problems, problems that may require greater resources and scientific expertise than states can offer, and areas in which ensuring a minimum level of protection for patients and the public health is particularly important.

\section{B. A Public Health Framework for Federal Regulation}

Rather than considering the merits of federalizing a particular aspect of medical practice oversight, this Article proposes that federal regulation is generally warranted when medical practice causes or contributes to a national public health problem that the states cannot address. Because public health problems, by definition, occur on a community or population level, ${ }^{327}$ coordinated, federal efforts are likely necessary to effectively address national public health problems. However, when the states have already established essentially consistent and well-functioning schemes to regulate areas of medical practice that implicate the national public health, there may be no need for the federal government to intervene. Additionally, depending on the particular problem, federal oversight need not preempt all state oversight. By limiting the proposal to circumstances in which there is both a national public health concern and a lack of adequate state oversight, this framework attempts to strike the right balance between expanding federal options for addressing public health problems, avoiding ineffective federal interference with medical practice, and preserving well-functioning state regulation consistent with federalism values. Additionally, by focusing on national issues, this proposal is consistent with, although not identical to, the circumstances in which the federal government has been able to implement medical practice regulation. ${ }^{328}$

Considering whether the six examples of federal medical practice regulation provided in section III.A would be warranted under this framework helps to clarify it. The CSA, the FDA's pre-market review of medical products and REMS requirements, and Medicare coverage decisions would all be warranted federal regulatory schemes under this framework. In determining whether a particular law is intended to address a national public health problem, it is helpful to consider Congressional intent, as well as public health agencies' positions on the problem addressed by the law. Congress established each of these regulatory schemes, at least in part, to address a national public health problem, and agencies have endorsed the public health

326. See, e.g., Schapiro, supra note 52, at 285.

327. See, e.g., Gostin, supra note 49 , at 4.

328. See supra section III.A. 
nature of these schemes. ${ }^{329}$ The CSA and the FDA's pre-market review of medical products and REMS requirements, by virtue of addressing scientifically complex problems associated with products that cross state lines, address problems that states are unlikely to effectively regulate. Likewise, states do not possess sufficient resources for a program like Medicare, and to administer such a program, the federal government must make coverage decisions.

The Partial-Birth Abortion Ban Act and the provision prohibiting offlabel use of $\mathrm{HGH}$, on the other hand, would not be appropriate exercises of federal authority because neither law was enacted to address a national public health problem. The Congressional findings in the Partial-Birth Abortion Ban Act suggest that Congress enacted the law to "express[] respect for the dignity of human life," and protect the medical profession from reputational harms associated with performing what Congress deemed a "gruesome" procedure, rather than to address a public health concern about the safety or effectiveness of the procedure itself. ${ }^{330}$ Similarly, to the extent that Congress prohibited off-label use of HGH to address cheating in sports, rather than to solve a public health problem, that prohibition is an unwarranted exercise of federal authority. ${ }^{331}$ When regulation hinges on particular values for which there is no compelling public health need for national uniformity, rather than on addressing public health problems, states might be better positioned to account for cultural and local diversity in views.

\section{Advantages of the Framework}

This framework offers several advantages. First, the position that the federal government does not regulate medical practice is simply incorrect,

329. See, e.g., Comprehensive Drug Abuse Prevention and Control Act of 1970, Pub. L. No. 91-513, 84 Stat. 1236, 1236, 1242 (identifying the prevention of drug abuse as one purpose of the Act, which includes the CSA); OBERLANDER, supra note 47, at 17-35 (describing Medicare's goal to bring medical care for the elderly into the mainstream); Psaty \& Korn, supra note 201, at 2185 (explaining the public health rationale for enacting the REMS provisions); U.S. Food \& Drug Admin., What We Do, FDA, http://www.fda.gov/ aboutfda/whatwedo/ [http://perma.cc/MVV8-D996] ("FDA is responsible for protecting the public health by assuring the safety, efficacy and security of human . . . drugs, biological products, medical devices ....").

330. Partial-Birth Abortion Ban Act of 2003, Pub. L. No. 108-105 § 2(14)(J), 117

Stat. 1201, 1205; Gonzales v. Carhart, 550 U.S. 124, 157 (2007).

331. See supra notes 159-61 and accompanying text. 
and the distinction between regulating medical practice and medical products is porous. The CSA, the provision in the FDCA prohibiting offlabel use of HGH, the FDA's premarket review of medical products, and FDA-required REMS are all examples of medical product regulation that also reaches medical practice. ${ }^{332}$ To the extent arguments against federal regulation are premised on the notion that the federal government plays no role - or historically has never played a role - in regulating medical practice, those arguments are demonstrably wrong. Dispensing with the truism that the federal government abstains from regulating medical practice for a framework that explicitly acknowledges the role that the federal government plays will permit more transparency about that role. Additionally, by proposing a general framework to guide decisions about when to exert federal authority over medical practice, this framework should promote a more principled approach to federal oversight.

Second, this framework ought not to run afoul of traditional notions of federalism. While some may oppose this framework on the ideological ground that greater federal power is inherently bad, ${ }^{333}$ state regulation of medical practice arose at a time when medical practice was decidedly local in nature-which is no longer the case. ${ }^{334}$ "Federalism is rooted in the belief that issues that are not national in scope or significance are most appropriately addressed by the level of government closest to the people." 335 But "Our Federalism" does not require absolute deference to states' authority; instead, it envisions a role for the federal government in solving national problems. ${ }^{336}$ By limiting federal intervention to activities causing or contributing to a national public health problem that states are not equipped to address, the federal role conceived by this framework is consistent with "Our Federalism." It recognizes the comparative advantages that states may have in some circumstances, and does not call for federal preemption of all medical practice oversight, even in situations in which medical practice contributes to a national public health problem. For example, while a federal review of the safety and effectiveness of infertility treatments and practices, such as in vitro fertilization (IVF) techniques, would likely be more efficient and expert than duplicative state efforts, ${ }^{337}$

332. See discussion in sections III.A.1 a and b, and 2.a and b.

333. Cf. Huberfeld, supra note 53, at 435 ("[S]ome would oppose centralization [of Medicaid] on the ideological grounds that more federal government power is bad, and more state or local power is good.").

334. See, e.g., MoHr, supra note 23, at 9-21.

335. Exec. Order No. 13,132, 64 Fed. Reg. 43,255, 43, 255 (Aug. 4, 1999).

336. Younger v. Harris, 401 U.S. 37, 44 (1971). As Nicole Huberfeld explains, "Justice Black coined the phrase 'Our Federalism' in this case." Huberfeld, supra note 53 , at 454 n.112.

337. See King, supra note 24, at 329-31, 338. 
there may good reasons why certain practices differ among states. Some states offer insurance coverage for infertility treatment, while others do not, ${ }^{338}$ and differences in insurance coverage may drive practitioners and patients to make different decisions about treatment, such as determining how many embryos to implant in a woman undergoing IVF. Accordingly, while the federal government may be best able to regulate certain aspects of infertility treatments, states may have comparative advantages in regulating other aspects.

Finally, insofar as the argument that the federal government should not regulate medical practice has limited the options that federal lawmakers seriously consider, this framework should open new possibilities for federal legal action to address serious public health problems. As an example, Congress expressed concern about intruding on state regulation of traditional drug compounding through the Drug Quality and Security Act, and that concern, arguably, drove Congress to provide more limited federal oversight of compounding than it could have in the Act. ${ }^{339}$ Under this framework, however, federally regulating drug compounding - regardless of whether it constitutes medical practice - would be considered appropriate because it contributes to a national public health problem that states cannot address.

\section{Addressing Critiques}

Although the proposed framework offers advantages, it may also be susceptible to several critiques. First, proposing that the federal government regulate only those activities that cause or contribute to a national public health problem that states cannot address might trade one line-drawing problem for another. While the line between regulating medical practice versus medical products is not readily apparent, some scholars have criticized the notion of distinguishing between individual and public health, ${ }^{340}$ and it may be difficult to determine what constitutes a national public health problem versus a local or individual health problem. It is likely to be even more challenging to determine what is both a national public health problem and a problem that the states cannot address. This framework, thus, will be most helpful at two ends of a spectrum - when it is very clear there is

338. See State Infertility Insurance Laws, AM. SOC'y FOR REPROD. MED., http://www. asrm.org/insurance.aspx [http://perma.cc/JQ92-LL23] (last visited Feb. 12, 2015).

339. See supra notes 11-15 and accompanying text.

340. See, e.g., Gostin, supra note 49, at 3-4; Arah, supra note 49, at 235. 
a national public health problem that states cannot address, and when it is very clear those circumstances do not exist. But determining what constitutes a national problem for which state regulation will be inadequate is a question we routinely trust to Congress and administrative agencies in contexts other than medicine. ${ }^{341}$ Consequently, this framework tasks Congress and administrative agencies with an inquiry that is within their institutional expertise. Because line-drawing problems are difficult, if not impossible, to completely eradicate, focusing Congress and administrative agencies' attention on inquiries within their institutional expertise, and providing them with principled bases on which to make their decisions, may be the most viable solution.

Second, there may be concerns that acknowledging and, in some circumstances, expanding a federal role in overseeing medical practice will lead to the government curtailing individual liberties in the name of public health. It is true that there is a history of governments using, or trying to use, public health authorities in this way. For example, in the early- and mid-twentieth century, a majority of states passed laws permitting or mandating the sterilization of mentally ill persons, or other persons deemed "socially inadequate." 342 In the early 1990 s, when mortality from HIV/AIDS was rising and treatment options were very limited, Senator Jesse Helms proposed requiring medical practitioners to be tested for HIV and criminalizing the practice of medicine by HIV positive individuals. ${ }^{343}$ More recently, in the name of preventing the transmission of Ebola, local schools implemented policies that excluded children who, according to the CDC, were not at a high enough risk to merit exclusion. ${ }^{344}$ Although the framework proposed in this Article will not eliminate the possibility that civil liberties will be curtailed in the name of the public health, the risk of such abuses already exists under the current framework. ${ }^{345}$ To the

341. Cf. Abbe R. Gluck, Our (National) Federalism, 123 YALE L. J. 1996, 1998 (2014) (describing Congress's role and noting "federalism now comes from federal statutes"); Gillian E. Metzger, Federalism Under Obama, 53 WM. \& MARY L. REV. 567, 570 (2011) ("Critical decisions about the actual scope of state powers and autonomy will be made not in Congress or in the courts, but in the halls of agencies ....").

342. See Paul A. Lombardo, Three Generations, No Imbeciles: Eugenics, the SuPREME COURT, AND BUCK V. BELL ix-xiv (2008); Paul A. Lombardo, Public Health or AIDS Hysteria? Helms's Proposal, BioLAw, Dec. 1991, at S:681, S:683 [hereinafter Lombardo, Public Health or AIDS Hysteria?].

343. See Lombardo, Public Health or AIDS Hysteria?, supra note 337, at S:681.

344. See, e.g., Wendy Hensel, Civil Rights Have a Place in Conversation, ATLANTA J. CONST., Nov. 21, 2014, at A16.

345. See, e.g., supra notes 342-44 and accompanying text. In addition, depending on one's view of abortion, the Partial-Birth Abortion Ban Act may serve as evidence of the federal government curtailing individual liberties in the name of medical practice regulation, rather than in the name of public health. 
extent the proposed framework enables an expansion of federal oversight of medical practice, it is not clear that the federal government is more prone to these abuses than state governments are. Moreover, similar to line-drawing problems, governments using public health authorities to curtail civil liberties may be a particularly difficult problem to eradicate. The framework proposed in this Article does not seem likely to exacerbate the problem - as its purpose is not to expand federal regulation per se, but rather to make that regulation more transparent and coherent.

Third, federal regulation under the framework proposed in this Article may restrict medical practitioners' flexibility, as well as stifle policy experimentation by state governments. ${ }^{346}$ The framework is likely to limit medical practitioners' discretion in clinically meaningful ways by requiring that, in certain circumstances, care be provided to patients not based on a practitioner's judgment about that individual patient's best interests, but instead based on a public health policy goal. As an example, the DEA's existing scheme for regulating pain medication has been criticized for making it difficult for practitioners to treat individual patients with legitimate needs for such drugs, in the name of addressing the prescription drug abuse problem. ${ }^{347}$ However, that regulation under the framework proposed in this Article might result in patients receiving non-individualized, or even suboptimal, care in certain circumstances should not necessarily weigh against implementing it. The framework would change clinical practice only in those circumstances in which a judgment has been made that the public health should be prioritized over an individual's health. ${ }^{348}$ Indeed, courts and scholars have recognized that individual interests may be restrained when "the safety of the general public" demands it. ${ }^{349}$ Likewise,

346. See, e.g., Chemerinsky, supra note 302, at 525; McConnell, supra note 302, at 1499.

347. See, e.g., Ballantyne, supra note 21 , at 812 .

348. Moreover, the interests of the public health and the interests of the individual patient may be aligned in certain situations. For example, prescribing an antibiotic for a patient that has a viral condition benefits neither the individual patient nor the public health. See section IV.C.1.a., infra.

349. Jacobson v. Massachusetts, 25 S. Ct. 358, 362 (1905); see, e.g., James F. Childress et al., Public Health Ethics: Mapping the Terrain, 30 J.L. MED. \& ETHICs 170, 171-72 (2002); Wendy E. Parmet, Valuing the Unidentified: The Potential of Public Health Law, 53 JURIMETRICS J. 255, 265 (2013). 
when state experimentation leads to a "race to the bottom" that threatens the public health, it would be reasonable to limit such experimentation. ${ }^{350}$

Related to concerns about federal regulation of medical practice prioritizing public health over individual health, there might be concerns about supplanting medical practitioners' expert judgments with those of federal lawmakers. ${ }^{351}$ In other words, there might be concerns that this framework will permit federal lawmakers to establish unwise medical policies that will be difficult to modify. But in certain instances, federal actors may be better positioned than individual practitioners, professional organizations, or state governments to detect problems arising from medical practice and determine appropriate policies to address such problems. The FDA's authority to require REMS offers an example. Risks associated with certain uses of drugs, and plans to mitigate those risks, may require the comprehensive data and scientific expertise of the FDA. Additionally, even if this framework enables the federal government's role to expand over time, a federal regulatory scheme would not necessarily lead to more interference with practitioner discretion than a state-based scheme-because states can also exert substantial control over many aspects of medical practice. ${ }^{352}$

Fourth, because federal authorities are more distant than state authorities, enforcing federal medical practice requirements may be challenging. ${ }^{353}$ There is some evidence that existing efforts to federally regulate medical practice currently face enforcement problems. As an example, some commentators estimate that thirty percent of prescriptions for HGH are off-label, despite the prohibition on such prescriptions. ${ }^{354}$ Questions also have been raised about whether the FDA can effectively enforce REMS requirements. ${ }^{355}$ Although federal enforcement difficulties certainly exist, it is not clear that federal authorities have worse enforcement records than state authorities with more limited resources. Additionally, federal requirements may have an expressive value that a patchwork of state laws does not. Especially because federal oversight of medical practice is considered unusual, federally regulating a particular area of medical practice

350. Cf. Glicksman \& Levy, supra note 309, at 597-98 (describing the "race to the bottom" phenomenon in the context of climate change policy).

351. See, e.g., Gottlieb, supra note 149.

352. See id.

353. Cf. Sage \& Hyman, supra note 24, at 823; McConnell, supra note 302, at 1508.

354. See, e.g., Mary Lee Vance, Can Growth Hormone Prevent Aging?, 348 N. EnG. J. MED. 779, 780 (2003).

355. See Dep't of Health \& Human Servs., Office of Inspector Gen., FDA LACKS COMPREhEnSive Data To Determine Whether Risk Evaluation and Mitigation Strategies ImPROVe Drug SAFETy 22 (2013), available at https://oig.hhs. gov/oei/reports/oei-04-11-00510.pdf [https://perma.cc/G6X5-NHH5]. 
may underscore that area's importance to the public health, educate practitioners and patients about its importance, and help shift social norms. ${ }^{356}$

Finally, instead of acknowledging a federal role in regulating medical practice, one might propose eliminating existing areas of federal oversight to preserve state primacy in regulating medical practice. That solution, however, is not only impractical - it would be politically impossible to dissolve many federal health programs such as Medicare ${ }^{357}$-it would have disastrous public health effects. It, for example, would require dismantling modern FDA regulation of medical products, and reverting to an era of widespread marketing of fraudulent or adulterated drugs and devices. ${ }^{358}$ As a series of articles in The New Yorker reported, before the FDA was authorized to review drugs' effectiveness in 1962, "it was frequently impossible for even a specialist to find out what a given drug might do for a patient," a number of drugs "had little efficacy at all," "a good part of the advertising was misleading - in fact, [] some of it was downright fraudulent," and it took the government "ten years to ban Hoxey's Cancer Cure-a worthless concoction that sick people spent three to four hundred dollars per treatment for, when they might have been saved by surgery or X-ray therapy." 359

\section{Applying the Framework: Antibiotic Resistance}

As discussed above, this Article proposes that the federal government should regulate medical practice when it causes or contributes to a national public health problem that the states cannot address. To illustrate how this framework could work in practice and open new options for addressing public health crises, this section discusses one example for which the framework would clearly support federal regulation: the problem of antibiotic resistance. ${ }^{360}$ This section first argues that medical practice that

356. Cf. Cass R. Sunstein, On the Expressive Function of Law, 144 U. PA. L. REV. 2021, 2028 (1996) (describing various expressive values of law).

357. See Moncrieff, supra note 300 , at 882-83.

358. Cf. CARPENTER, supra note 297, at 73-118 (describing the drug market before the enactment of the Federal Food, Drug, and Cosmetic Act of 1938).

359. Richard Harris, The Annals of Legislation: The Real Voice-I, THE NEW YORKER, Mar. 14, 1964, at 63-64; Richard Harris, The Annals of Legislation: The Real Voice-III, THE NEW YORKER, Mar. 28, 1964, at 50.

360. The problem is also characterized more broadly as antimicrobial resistance because, in addition to bacteria, other microbes - fungi, viruses, and parasites - have developed resistance to existing drugs. See, e.g., About Antimicrobial Resistance: A Brief 
contributes to antibiotic resistance is an appropriate candidate for federal regulation, and second considers how federal regulation might be implemented.

\section{Antibiotic Resistance Fits the Framework}

Medical practice that contributes to antibiotic resistance is an appropriate target for federal regulation because antibiotic resistance represents a serious threat to the national public health that the states cannot effectively address.

\section{a. The National Antibiotic Resistance Problem}

Congress and major public health organizations have recognized drugresistant bacteria as a grave national - and international - public health problem. ${ }^{361}$ The CDC reports that each year at least 2 million people in the United States are infected with drug-resistant bacteria, 23,000 die as a direct result of those infections, and many more die from conditions that are complicated by the infections. ${ }^{362}$ The World Economic Forum estimates that 80,000 people in China, and 25,000 people in Europe, die each year from hospital-acquired infections with drug-resistant bacteria. ${ }^{363}$ And the World Health Organization (WHO) reports "very high rates" of antibiotic resistance worldwide. ${ }^{364}$

There is good reason to be concerned about antibiotic resistant bacteria. Antibiotics provide treatments for infections that are serious and lifethreatening, such as sepsis, as well as common illnesses, such as strep throat, that are generally viewed as low risk but were untreatable and

Overview, CEnTERs fOr Disease CONTROL \& Prevention, http://www.cdc.gov/ drugresistance/about.html [http://perma.cc/DM5Z-RMTZ] (last updated Sept. 16, 2013).

361. See, e.g., 158 CONG. REC. S4610-30 (daily ed. June 26, 2012) (statement of Sen. Mikulski); World Health Org., Antimicrobial Resistance: Global Report on SURVEILLANCE 2014 9-30 (2014) [hereinafter WHO REPORT], available at http:// apps.who.int/iris/bitstream/10665/112642/1/9789241564748_eng.pdf?ua=1 [http://perma.cc/ 3SHU-88EH]; Ctrs. For Disease Control \& Prevention, Antibiotic Resistance THREATS IN THE UNITED STATES, 201311 (2013) [hereinafter CDC REPORT], available at http://www.cdc.gov/drugresistance/threat-report-2013/pdf/ar-threats-2013-508.pdf [http://perma. cc/T9NG-4HZ5]; U.S. FOOD \& DRUG ADMIN., GUIDANCE FOR INDUSTRY: THE JUDICIOUS Use of Medically Important Antimicrobial Drugs in FoOd-Producing ANimals 3 (Apr. 13, 2012), available at http://www.fda.gov/downloads/animal veterinary/guidance complianceenforcement/guidanceforindustry/ucm216936.pdf [http://perma.cc/4ZP2-EWFL].

362. CDC REPORT, supra note 361 , at 11 .

363. WORLD ECONOMIC FORUM, GLOBAL RISKS 30 (8th ed. 2013) [hereinafter WEF REPORT], available at http://www3.weforum.org/docs/WEF_GlobalRisks_Report_2013.pdf [http://perma.cc/JZ2R-VNYR].

364. WHO REPORT, supra note 361 , at $\mathrm{x}$. 
sometimes fatal before antibiotics were developed. ${ }^{365}$ Antibiotics also enable treatments for conditions other than infections. For example, chemotherapy and surgery pose infection risks, and would be substantially more dangerous without effective antibiotics. ${ }^{366}$ The threat of antibiotic resistance, thus, is not just that we will lose the ability to treat infections, but also that we will lose the capacity to safely treat many other diseases and conditions. Indeed, the CDC concluded that the consequences of failing to act to stop the spread of drug-resistant bacteria are "potentially catastrophic," ${ }^{367}$ the World Economic Forum cited drug-resistant bacteria as "arguably the greatest risk . . to human health," 368 and the DirectorGeneral of the WHO said "[a] post-antibiotic era means, in effect, an end to modern medicine as we know it." $" 369$

Antibiotic resistance arises because bacteria are living organisms that evolve and adapt to survive in their environments. ${ }^{370}$ Although any use of antibiotics selects for resistant bacteria by killing those that are not, misuse unnecessarily exacerbates this effect. ${ }^{371}$ Antibiotic misuse includes using antibiotics to promote animal growth. ${ }^{372}$ It also includes the medical use of antibiotics at doses too low to effectively cure an infection, for conditions that will not respond to antibiotics such as viral conditions, or for lengths

365. See Ctrs. for Disease Control \& Prevention, Achievements in Public Health, 1900-1999: Control of Infectious Diseases, 48 MorbidiTy \& MORTALITY WKLY. ReP. 621 (July 30, 1999), http://www.cdc.gov/mmwr/preview/mmwrhtml/mm4829a1.htm [http://perma. cc/GGN5-K5UM].

366. See, e.g., WEF REPORT, supra note 363, at 30; CDC REPORT, supra note 361, at 24.

367. CDC REPORT, supra note 361, at 6.

368. WEF REPORT, supra note 363 , at 28 .

369. Id. at 29.

370. See Antimicrobial (Drug) Resistance, NAT'L InSt. Of HeAlth, NAT'L Inst. OF ALLERGY AND INFECTIOUS DISEASE, http://www.niaid.nih.gov/topics/antimicrobialresistance/ understanding/pages/causes.aspx [http://perma.cc/SER6-EG42] (last updated Dec. 21, 2011).

371. See Brad Spellberg et al., The Future of Antibiotics and Resistance, 368 NEw. ENG. J. MED. 299, 299-300 (2013).

372. Because using antibiotics in livestock feed does not involve medical practice, it is beyond the scope of this Article. It does, however, play a significant role in contributing to the antibiotic resistance problem. See generally U.S. FoOD \& DRUG ADMIN., PHASING out CERTAin ANTIBIOTIC USE In FARM ANimAls (2013), available at http://www.fda. gov/downloads/ForConsumers/ConsumerUpdates/UCM378197.pdf [http://perma.cc/269UCW5E] (discussing a voluntary plan to phase out the use of certain antibiotics in farm animals in an effort to slow down antimicrobial resistance). 
of time shorter or longer than necessary to cure an infection. ${ }^{373}$ Even without exposure to antibiotics, some level of resistance will occur in nature. ${ }^{374}$ In 2012, scientists reported finding drug resistance in bacteria, including resistance to synthetic antibiotics not created until the twentieth century, in a cave that had been isolated from the surface for at least four million years, ${ }^{375}$

Antibiotic resistance is fundamentally a national and international problem, both in scope and significance. ${ }^{376}$ Antibiotic-resistant bacteria can quickly and easily spread across state and national boundaries. ${ }^{377}$ For example, drug-resistant gonorrhea was first identified in Hawaii and California in the late 1990s and early 2000s, but had spread throughout the United States by $2007 .{ }^{378}$ Behaviors that may seem local in nature, such as unprotected sexual activity, or more relevant to this Article, practitioners' antibiotic prescribing decisions, can contribute to the development of antibiotic resistant bacteria capable of crossing state lines. ${ }^{379}$ In addition, such infections cost a tremendous amount of money. The CDC estimates that drug-resistant infections cost the United States as much as $\$ 20$ billion in direct health care expenses, and $\$ 35$ billion in lost productivity. ${ }^{380}$

\section{b. States Cannot Adequately Address the Problem}

Although a number of states have enacted laws intended to address medical practice that contributes to antibiotic resistance, state efforts are likely insufficient. ${ }^{381}$ State laws primarily focus on tracking infections.

373. See CDC REPORT, supra note 361, at 41-43; Aaron S. Kesselheim \& Kevin Outterson, Fighting Antibiotic Resistance: Marrying New Financial Incentives, 29 HeALTH AFF. 1689, 1690 (2010).

374. See Spellberg et al., supra note 371, at 300.

375. See Kirandeep Bhullar et al., Antibiotic Resistance Is Prevalent in an Isolated Cave Microbiome, PLOS ONE, Apr. 2012, at 2.

376. Although the problem is not confined to the United States, this Article focuses on the United States to illustrate how the framework for federally regulating medical practice could work in this country.

377. See, e.g., CDC REPORT, supra note 361, at 11; Sage \& Hyman, supra note 24, at 824 .

378. See, e.g., Lauren F. Friedman, Super Gonorrhea Is on the Rise in the United States, Bus. INSIDER (Mar. 12, 2014, 1:14 PM), http://www.businessinsider.com/cipro floxacin-resistance-and-gonorrhea-incidence-2014-3\#ixzz2vlzm8jzU [http://perma.cc/FC287UNW].

379. See CDC REPORT, supra note 361, at 41-43.

380. See id. at 11. Likewise, the WHO reports that the international economic effects of antibiotic resistance are "disturbing." WHO REPORT, supra note 361, at xix. Ten years ago, antibiotic resistance was projected "to cause a fall in real gross domestic product (GDP) of $0.4 \%$ to $1.6 \%$, which translates into many billions of today's dollars globally." Id.

381. See Sage \& Hyman, supra note 24 , at 824. 
All fifty states require that certain diseases be reported to the state, ${ }^{382}$ with some requiring reporting of particular infections with antibiotic-resistant organisms. For example, Arkansas requires that practitioners report infections with Vancomycin-resistant enterococci. ${ }^{383}$ States may voluntarily report such disease cases to the CDC for national aggregation and monitoring. ${ }^{384}$

In addition to mandating reporting, several states have enacted laws explicitly aimed at preventing the spread of methicillin resistant staphylococcus aureus (MRSA) or Multi-Drug Resistant Organisms (MDROs). ${ }^{385}$ The laws generally require that hospitals screen patients at risk for contracting MRSA or MDROs, and if a patient is infected, take steps to prevent the infection's spread, such as isolating the patient and ensuring that hospital staff practice appropriate hygiene like hand washing. ${ }^{386}$ Although these requirements apply to hospitals, they indirectly regulate practitioner behaviors that contribute to the spread of drug-resistant bacteria.

States efforts, however, have not included comprehensive laws to incentivize or require appropriate antibiotic prescribing. ${ }^{387}$ This gap is

382. See, e.g. National Notifiable Disease Surveillance System (NNDSS), Data Collection and Reporting, CENTERS FOR DiseASE CONTROL AND PREVENTION, http://wwwn. cdc.gov/nndss/script/DataCollection.aspx [http://perma.cc/E4VW-E6HQ] [hereinafter NNDSS].

383. See Arkansas Department of Health (ADH) Mandatory Reportable Diseases List and Instructions, ARK. DEP'T OF HEALTH (Sept. 1, 2014), available at http://www. healthy.arkansas.gov/programsServices/epidemiology/Documents/ReportableDisease.pdf [http://perma.cc/J27Z-YHEJ]. Vancomycin is an important hospital-based antibiotic, and infections with vancomycin-resistant enterococci are associated with increased mortality. See, e.g., Establishing a List of Qualifying Pathogens Under the Food and Drug Administration Safety and Innovation Act, 78 Fed. Reg. 35155, 35162 (proposed June 12, 2013); Kevin Outterson, The Legal Ecology of Resistance: The Role of Antibiotic Resistance in Pharmaceutical Innovation, 31 CARDOZO L. REV. 613, 626 (2010).

384. See NNDSS, supra note 382.

385. See Cal. Health \& Safety Code $\S 1255.8$ (West 2014); Conn. Gen. Stat. AnN. § 19a-490p (West 2010); 110 Ill. Comp. Stat. AnN. 330/7 (West 2013); 410 ILL. Comp. Stat. AnN. 120/10 (West 2013); MinN. Stat. AnN. § 144.585 (West 2010); 40 PA. Cons. Stat. $\S 1303.403$ (2010); TENN. CODE AnN. § 68-11-269 (2008); WASH. REV. Code ANN. $§ 70.41 .430$ (West 2011).

386. See e.g., Cal. Health \& SAFEty Code $§ 1255.8$ (West 2014),

387. Arizona restricts how optometrists, but not physicians, prescribe antibiotics. ARIZ. REv. StAT. ANN. § 32-1706 (2010). In addition, a few states where Lyme disease is prevalent have expressly permitted licensed physicians to prescribe long-term antibiotic therapy for patients diagnosed with Lyme disease, suggesting that physicians in those states may have been subject to - or worried about - disciplinary actions from state medical boards for prescribing long-term courses of antibiotics. See CONN. GEN. STAT. ANN. § 20- 
troubling because as many as fifty percent of antibiotics used in the United States are used inappropriately. ${ }^{388}$ With the pipeline for new antibiotics dwindling because antibiotics offer a lower return on investment than other classes of drugs, some have expressed concern that any limits on antibiotic prescribing - at the federal or state level-might reduce the potential profits that companies can hope to reap, leading to a further diminished antibiotic pipeline. ${ }^{389}$ There are, however, ways to address this concern that do not depend on increasing antibiotic sales by permitting dubious uses. For example, this tension between the need to both incentivize antibiotic development and curtail inappropriate antibiotic uses might be resolved by de-linking antibiotic profits from antibiotic sales volume, as Kevin Outterson has proposed. ${ }^{390}$ Concerns about the antibiotic pipeline, therefore, do not support a permissive policy with respect to practitioners' antibiotic prescribing decisions. There may also be concerns that federal laws or regulations governing antibiotic prescribing decisions will not account for legitimate clinical exceptions to general prescribing rules. It, however, may be possible to design laws or regulations with sufficient flexibility to allow for clinically important exceptions, or it may be worth accepting some risk that a few individual patients will receive suboptimal care to promote the public health through better antibiotic prescribing practices overall.

In short, the existing, and incomplete, patchwork of state laws has not halted the spread of drug-resistant bacteria. While legal efforts to regulate practitioners' behaviors that contribute to resistance will not eliminate resistance, for such efforts to be most effective they must be nationally coordinated, and backed by resources that will enable long-term policies. ${ }^{391}$ Thus, the states are not likely to effectively regulate medical practice that contributes to antibiotic resistance. Additionally, professional self-regulation does not seem to be effectively addressing practitioner behaviors that contribute to resistance. For example, twenty-six organizations, including the American Academy of Pediatrics and the Infectious Diseases Society of America (IDSA), which represents health care professionals who specialize

14m (West 2010); MASS. GEN. LAWs ANN. ch. 112, § 12DD (West 2011); R.I. GEN. LAWS ANN. § 5-37.5-4 (West 2008).

388. See CDC REPORT, supra note 361, at 11.

389. See, e.g., Richard P. Wenzel, The Antibiotic Pipeline-Challenges, Costs, and Values, 351 New EnG. J. MeD. 523 (2004).

390. See Kevin Outterson, New Business Models for Sustainable Antibiotics, in Centre on Global Health Security Working Group Papers, Working Groups on ANTIMICROBIAL ReSISTANCE, PAPER 16 (Feb. 2014), available at http://www.chathamhouse. $\mathrm{org} / \mathrm{sites} /$ files/chathamhouse/public/Research/Global\%20Health/0214SustainableAntibio tics.pdf [http://perma.cc/CU94-JPFB].

391. Cf. Sage \& Hyman, supra note 24, at 823. 
in infectious diseases, have jointly worked to promote antibiotic stewardship among medical professionals. ${ }^{392}$ Nevertheless, as noted above, as many as fifty percent of the antibiotics prescribed in the United States continue to be inappropriately used. ${ }^{393}$

\section{Implementing the Framework for Antibiotic Resistance}

The CDC has identified four goals for addressing the antibiotic resistance problem, the first three of which implicate aspects of medical practice that could be regulated under the framework proposed in this Article. First, reducing misuse of antibiotics is "[p]erhaps the single most important action needed to greatly slow down the development and spread of antibiotic-resistant infections." 394 Second, tracking infections with drugresistant bacteria provides the opportunity to learn more about such infections, including whether there are particular risk factors for infection that can be mitigated in the future. ${ }^{395}$ Third, preventing infections with drug-resistant bacteria is critical because it reduces the need for antibiotic use, thereby helping to slow the development of resistance, and limits the spread of the drug-resistant bacteria themselves. ${ }^{396}$ Finally, new treatments for bacterial infections are needed. ${ }^{397}$

Thus far, federal legal efforts have primarily focused on the fourth goal-developing new antibiotics. For example, the Food and Drug Administration Amendments Act of 2007 included limited provisions intended to encourage antibiotic innovation, and specifically provided that the provisions did not "restrict, in any manner, the prescribing of antibiotics by physicians." 398 The Food and Drug Administration Safety and Innovation Act of 2012 included more extensive provisions - known as the Generating Antibiotic Incentives Now (GAIN) provisions-to encourage antibiotic development by providing certain drugs extended

392. See Carolyne Krupa, 26 Organizations Team Up To Fight Antibiotic Resistance, AM. MED. NEws, Nov. 26, 2012, http://www.amednews.com/article/20121126/ profession/311269933/6/ [http://perma.cc/UV9J-MCB9].

393. See CDC REPORT, supra note 361 , at 11.

394. Id. at 31 .

395. See id. at 39.

396. See id. at 32.

397. See id. at 44 .

398. Food and Drug Administration Amendments Act of 2007, Pub. L. No. 110-85 $\S \S 1111-1114,121$ Stat. 823, 976. 
periods of marketing exclusivity and a fast-tracked FDA approval process. ${ }^{399}$ The framework proposed in this Article would support federal legal action that moves beyond incentivizing antibiotic development, and focuses on the CDC goals that implicate medical practice.

Federal regulation in these areas could be accomplished in three ways, the first of which would be for Congress to enact new legislation to directly regulate medical practice that contributes to resistance. Legislation could prohibit practitioners from inappropriately prescribing or dispensing antibiotics, similar to the provision prohibiting off-label use of HGH. ${ }^{400}$ Although a prohibition on inappropriately prescribing and dispensing antibiotics may not perfectly align with the FDA-approved labeling if there are medically appropriate uses that are not approved, such a prohibition could be added to the FDCA and enforced by the FDA, which already has experience enforcing the prohibition of HGH's off-label use. There may be evidentiary difficulties with enforcing a requirement that practitioners refrain from inappropriate prescribing or dispensing of antibiotics. It may be difficult for the government to obtain information about prescribing and dispensing practices, and even if it has access to that information, it may be difficult to demonstrate that a particular prescribing or dispensing decision was inappropriate. For example, it may be difficult to prove an antibiotic was prescribed for a viral, rather than a bacterial, condition. Nevertheless, an explicit federal prohibition on inappropriate medical uses may carry an expressive value, and would allow the federal government to impose penalties in circumstances where it does possess the evidence to determine a use was inappropriate.

In addition to prohibiting inappropriate prescribing and dispensing of antibiotics, Congress could enact legislation to directly require that practitioners federally report infections with antibiotic-resistant bacteria and undertake actions to prevent the spread of resistant infections when they are diagnosed. The CDC may be the appropriate agency to implement and enforce such requirements because it already has a reporting system in place and guidelines for preventing the spread of infections, albeit of a voluntary nature. ${ }^{401}$

Laws restricting prescribing, requiring practitioner reporting, or mandating practitioner actions to prevent the spread of infections could impose criminal or civil penalties on practitioners who violate the laws, including

399. Food and Drug Administration Safety and Innovation Act of 2012, Pub. L. No. 112-144 §§ 701-718, 126 Stat. 993, 1077-82.

400. 21 U.S.C. $\S 333(\mathrm{e})(2012)$.

401. See CDC REPORT, supra note 361, at 32; NNDSS, supra note 382. 
forfeiture of their state-issued licenses, similar to the CSA. ${ }^{402}$ While imposing such penalties on medical practitioners may seem draconian, serious penalties would underscore the grave public health stakes of antibiotic resistance. Additionally, such penalties are already imposed on medical practitioners who violate existing federal laws governing medical practice. ${ }^{403}$ Moreover, the enforcing agency could - and is likely to - exercise its discretion not to take action or seek the harshest penalties if the facts of a particular case warrant it. ${ }^{404}$

In addition to enacting legislation to directly regulate medical practice that contributes to resistance, Congress could enact new legislation to indirectly regulate such medical practice. For example, Congress might enact a law to require that hospitals - rather than practitioners - put in place measures to identify resistant infections and prevent their spread, similar to what some states have already done. ${ }^{405}$ IDSA has proposed several legislative changes that would indirectly control medical practice that contributes to resistance. One proposal is to create a "Limited Population Antibacterial Drug" approval pathway, which would explicitly authorize the FDA to approve antibiotics based on small studies for narrow indications and would require labels for such antibiotics to have a logo and other information signaling to practitioners that the drug should be used in a limited fashion. 406 Such labeling would encourage practitioners to appropriately prescribe the drugs, and may help to change standards of care. IDSA has also suggested that Congress require health care settings to establish antibiotic stewardship programs as a condition of participation in Medicare and Medicaid. ${ }^{407}$

Finally, because passing new legislation is politically challenging — and this may be particularly true for legislation that would regulate medical

402. See 21 U.S.C. $\S 853$ (2012); United States v. Singh, 390 F.3d 168, 190 (2d Cir. 2004).

403. See, e.g., 21 U.S.C. $\S \S 333(e), 853$ (2012).

404. See, e.g., Heckler v. Chaney, 470 U.S. 821,824 (1985).

405. See supra notes $385-86$ and accompanying text.

406. See InFECTIOUS Diseases Soc'y OF AM., LiMited Population ANTIBACTERIAL DRUG (LPAD) APPROVAL MECHANISM, available at http://www.idsociety.org/uploadedFiles/ IDSA/News_and_Publications/IDSA_News_Releases/2012/LPAD\%20one\%20pager.pdf [http://perma.cc/GA4H-PD2M].

407. See Infectious Diseases Soc'y of Am., Combating Antimicrobial Resistance: Policy Recommendations To Save Lives, 52 CliniCAl InfeCtious Diseases S397, S398 tbl.1 (2011). 
practice $^{408}$ - federal regulation of medical practice that contributes to antibiotic resistance might be most likely to occur pursuant to agencies' existing authority. IDSA has proposed that the FDA require REMS for antibiotics to address resistance. 409 Through its REMS authority, the FDA could indirectly control medical practitioners by, for example, requiring manufacturers to educate practitioners about appropriate prescribing practices and infection prevention measures, or ensure that an antibiotic only be dispensed when there is documentation that it has been appropriately prescribed. ${ }^{410}$ Such documentation could be a form that requires the prescriber to affirm that the prescription is appropriate, the patient being prescribed the antibiotic has a condition consistent with a bacterial infection, and the dose is sufficient but not excessive. The FDA is authorized to require a REMS when it is necessary to ensure that the benefits of a drug outweigh its risks, which are generally conceptualized as risks to the patient taking the drug rather than general risks to the public. ${ }^{411}$ That is, the risks that inappropriate antibiotic-prescribing and inadequate infection prevention measures pose to the public by contributing to resistance may not fit squarely within the statutory framework for requiring REMS. But there is some precedent for the FDA to consider harms to third parties when requiring REMS; for example, one of the goals of the REMS for transmucosal immediate release fentanyl products is to "[prevent] accidental exposure to children and others for whom [the drugs] are not prescribed." 412

CMS also might exercise its existing authority to indirectly regulate Medicare- and Medicaid-funded medical practice that contributes to resistance. CMS could incentivize appropriate prescribing through its coverage decisions. Such an action might be particularly important in

408. See supra section II.B.2.

409. See Derrick Gingery, Antibiotics Need REMS for Public, Not Patient, Safety Reasons, IDSA Says, THE PINK SHEET, Sept. 13, 2010, at 15.

410. See 21 U.S.C. § 355-1(f)(3) (2012). The FDA has not exercised its REMS authority to prohibit off-label prescribing of drugs and this Article is not necessarily proposing that the FDA restrict all off-label uses. To the extent that there are medically appropriate uses of antibiotics that are not approved, appropriate use may be a broader category than on-label use.

411. 21 U.S.C. $\S \S 355-1(\mathrm{a})$, (b) (2012).

412. U.S. Food \& Drug Admin., Transmucosal Immediate Release Fentanyl (TIRF) Risk EvaluATION AND MitigAtion StRATEGY (REMS) 2 (2014), available at http://www.fda.gov/downloads/Drugs/DrugSafety/PostmarketDrugSafetyInformationfor PatientsandProviders/UCM289730.pdf. Transmucosal immediate release fentanyl products are opioids that are intended to manage breakthrough pain in adults with cancer who routinely take other opioids for pain management. These products come in a variety of forms, including sublingual tablets and lozenges, that may increase the risk of accidental exposure to children. See Transmucosal Immediate-Release Fentanyl (TIRF) Medicines, FDA, http://www.fda.gov/Drugs/DrugSafety/InformationbyDrugClass/ucm282110.htm [http:// perma.cc/S4CW-XLR9] (last updated Mar. 21, 2014). 
light of recent research suggesting that inappropriate antibiotic use is widespread among Medicaid patients. ${ }^{413}$ CMS also has the authority to mandate that hospitals meet requirements "necessary" for "the interest of the health and safety of individuals who are furnished services in the institution" as a condition of participation in Medicare and Medicaid. ${ }^{414}$ CMS could exercise this authority to require that participating hospitals establish antibiotic-prescribing and infection-prevention policies. Although the first provision in the Medicare statute prohibits federal interference with medical practice, courts have generally rejected challenges to Medicare requirements on the ground that they impermissibly interfere with medical practice, and likewise, these requirements would likely be a permissible exercise of CMS's authority. ${ }^{415}$ In sum, medical practice that contributes to antibiotic resistance is one appropriate target for federal action under the framework proposed in this Article, and there are numerous mechanisms through which federal oversight might be implemented.

\section{CONCLUSION}

Conventional wisdom holds that the federal government rightfully regulates medical products, but the states should regulate medical practice. Concerns about upending this division of labor have endured even in the face of national public health disasters caused, at least in part, by medical practice. But, as this Article demonstrates, the federal government is already deeply entrenched in the regulation of medical practice, and possesses constitutional powers to continue to expand its regulatory reach. This federal role in medicine, however, is inconsistently and ineffectively defined, and at times, obfuscated.

This Article proposes principled criteria, which are consistent with the goals of federalism, for determining when a federal role is warranted. Instead of assigning oversight to states or the federal government based on whether an activity constitutes medical practice, Congress and federal administrative agencies should exert federal authority over medical practice that causes or contributes to a national public health problem that the states cannot address. While this framework will be most helpful in circumstances in which it is very clear these criteria are satisfied - or not satisfied-

413. See Pengxiang Li et al., Factors Associated with Antimicrobial Drug Use in Medicaid Programs, 20 EMERGING InFECTIOUS DisEASE 829, 831 (2014).

414. $\quad 42$ U.S.C. $§ 1395 x(e)(9)(2012)$.

415. See supra notes 229-30 and accompanying text. 
applying this framework to serious public health problems, such as antibiotic resistance, which do clearly satisfy the criteria will expand the options for addressing those problems through federal law. Federally regulating medical practice, by itself, will not solve public health problems, but Congress and federal administrative agencies ought to consider all available regulatory options that are constitutionally-authorized and, consistent with federalism values, are ones for which the federal regulation may be advantageous. 